University of Vermont

UVM ScholarWorks

Rubenstein School of Environment and Natural Rubenstein School of Environment and Natural Resources Faculty Publications

$5-1-2015$

\title{
Net carbon fluxes at stand and landscape scales from wood bioenergy harvests in the US Northeast
}

Anna M. Mika

University of Vermont

William S. Keeton

University of Vermont

Follow this and additional works at: https://scholarworks.uvm.edu/rsfac

\section{Recommended Citation}

Mika AM, Keeton WS. Net carbon fluxes at stand and landscape scales from wood bioenergy harvests in the US Northeast. Gcb Bioenergy. 2015 May;7(3):438-54.

This Article is brought to you for free and open access by the Rubenstein School of Environment and Natural Resources at UVM ScholarWorks. It has been accepted for inclusion in Rubenstein School of Environment and Natural Resources Faculty Publications by an authorized administrator of UVM ScholarWorks. For more information, please contact scholarworks@uvm.edu. 


\title{
Net carbon fluxes at stand and landscape scales from wood bioenergy harvests in the US Northeast
}

\author{
ANNA M. MIKA and WILLIAM S. KEETON \\ Rubenstein School of Environment and Natural Resources, University of Vermont, 81 Carrigan Drive, Burlington, Vermont \\ 05405, USA
}

\begin{abstract}
The long-term greenhouse gas emissions implications of wood biomass ('bioenergy') harvests are highly uncertain yet of great significance for climate change mitigation and renewable energy policies. Particularly uncertain are the net carbon $(\mathrm{C})$ effects of multiple harvests staggered spatially and temporally across landscapes where bioenergy is only one of many products. We used field data to formulate bioenergy harvest scenarios, applied them to 362 sites from the Forest Inventory and Analysis database, and projected growth and harvests over 160 years using the Forest Vegetation Simulator. We compared the net cumulative C fluxes, relative to a nonbioenergy baseline, between scenarios when various proportions of the landscape are harvested for bioenergy: $0 \%$ (non-bioenergy); 25\% (BIO25); 50\% (BIO50); or 100\% (BIO100), with three levels of intensification. We accounted for $\mathrm{C}$ stored in aboveground forest pools and wood products, direct and indirect emissions from wood products and bioenergy, and avoided direct and indirect emissions from fossil fuels. At the end of the simulation period, although $82 \%$ of stands were projected to maintain net positive C benefit, net flux remained negative (i.e., net emissions) compared to non-bioenergy harvests for the entire 160-year simulation period. $\mathrm{BIO} 25, \mathrm{BIO} 50$, and $\mathrm{BIO} 100$ scenarios resulted in average annual emissions of 2.47, 5.02, and 9.83 $\mathrm{Mg}^{\mathrm{C}} \mathrm{ha}^{-1}$, respectively. Using bioenergy for heating decreased the emissions relative to electricity generation as did removing additional slash from thinnings between regeneration harvests. However, all bioenergy scenarios resulted in increased net emissions compared to the non-bioenergy harvests. Stands with high initial aboveground live biomass may have higher net emissions from bioenergy harvest. Silvicultural practices such as increasing rotation length and structural retention may result in lower $\mathrm{C}$ fluxes from bioenergy harvests. Finally, since passive management resulted in the greatest net $C$ storage, we recommend designation of unharvested reserves to offset emissions from harvested stands.
\end{abstract}

Keywords: bioenergy, C flux, carbon neutral, fossil fuel offsets, landscape analysis, northern hardwoods, whole-tree harvest

Received 17 June 2013; revised version received 3 August 2013 and accepted 22 August 2013

\section{Introduction}

The temporal impacts of burning wood biomass for generating energy ('bioenergy') on long-term greenhouse gas emissions are uncertain (McKechnie et al., 2011), yet demand for wood bioenergy continues to increase in the United States and abroad (Buchholz et al., 2009). Although the carbon (C) emitted from wood bioenergy may eventually be re-sequestered through regeneration and increased growth rates in residual trees, (Eriksson et al., 2007; Malmsheimer et al., 2008; Nunery \& Keeton, 2010), there is uncertainty about the length of that recovery period (termed $\mathrm{C}$ 'debt') and the potential for a C 'dividend' in the longterm with fossil fuel offsets (avoided emissions; Table 1)

Correspondence: William S. Keeton, tel. +1 (802) 6562518 , fax +1 (802) 656 2623, e-mail: William.Keeton@uvm.edu and forest C sequestration (McKechnie et al., 2011; Mika \& Keeton, 2013). The long-term C impacts of bioenergy harvests are particularly complex because the kind of energy generated (e.g., electricity vs. heat) and type of fossil fuel replaced all impact the net $\mathrm{C}$ outcomes (Harmon \& Marks, 2002; Eriksson et al., 2007; Routa et al., 2011; Zanchi et al., 2012; Mika \& Keeton, 2013). A poorly explored though critical consideration is how bioenergy harvest at landscape scales and over multiple rotations affect net $C$ flux (see Table 1 for definition of terms; Gunn et al., 2012).

In this study, we sought to understand the effects of staggering bioenergy harvests, both spatially and temporally, on the net landscape C flux in the northeastern United States. We define a 'landscape' as a collection of stands that are harvested using different silvicultural prescriptions and scheduled independently. Although this landscape is not spatially explicit, it serves as a 
Table 1 Definitions of terms commonly used in this article

\begin{tabular}{|c|c|c|}
\hline Term & Definition & Unit \\
\hline Carbon storage & $\begin{array}{l}\text { Amount of carbon intact in the forest stand (aboveground live tree, aboveground dead tree, } \\
\text { coarse woody debris) and in wood products. These carbon stocks can also be called pools. }\end{array}$ & $\mathrm{MgCha}{ }^{-1}$ \\
\hline $\begin{array}{l}\text { Carbon } \\
\text { sequestration }\end{array}$ & $\begin{array}{l}\text { Carbon taken up by live trees through photosynthesis minus loss from respiration (Net } \\
\text { Primary Productivity). }\end{array}$ & $\mathrm{MgC} \mathrm{ha}{ }^{-1} \mathrm{yr}^{-1}$ \\
\hline Carbon emissions & $\begin{array}{l}\text { Amount of carbon lost from the following: decomposition of dead wood in forest stand } \\
\text { or from land filled wood products; combustion of bioenergy; combustion of fossil fuels } \\
\text { (see carbon offset); and indirect emissions (see below) from wood products, bioenergy, and } \\
\text { fossil fuels. }\end{array}$ & $\mathrm{MgC} \mathrm{ha}{ }^{-1}$ \\
\hline $\begin{array}{l}\text { Indirect carbon } \\
\text { emissions }\end{array}$ & $\begin{array}{l}\text { Carbon emitted as a result of harvesting/extracting, processing, and transporting wood } \\
\text { products, bioenergy, and fossil fuels. }\end{array}$ & $\mathrm{MgC} \mathrm{ha}{ }^{-1}$ \\
\hline Carbon offset & $\begin{array}{l}\text { Avoided carbon emissions from displaced fossil fuels that were not burned because } \\
\text { bioenergy was used instead. Includes avoided indirect emissions from fossil fuels. }\end{array}$ & $\mathrm{MgC} \mathrm{ha}{ }^{-1}$ \\
\hline Carbon flux & $\begin{array}{l}\text { Net difference between sequestered and emitted carbon. We use positive flux to indicate a } \\
\text { sink (net storage) and negative flux to indicate a source (net emissions) of carbon } \\
\text { to the atmosphere. }\end{array}$ & $\mathrm{MgC} \mathrm{ha}{ }^{-1}$ \\
\hline $\begin{array}{l}\text { Average annual net } \\
\text { cumulative } C \text { flux }\end{array}$ & $\begin{array}{l}\text { Accumulated stored carbon minus emissions from } 1 \text { year to the next, averaged over the } \\
\text { study period ( } 160 \text { years in this study). }\end{array}$ & $\mathrm{MgC} \mathrm{ha}{ }^{-1} \mathrm{yr}^{-1}$ \\
\hline $\begin{array}{l}\text { 160-year net } \\
\text { cumulative flux }\end{array}$ & $\begin{array}{l}\text { Accumulated stored carbon minus emissions from } 1 \text { year to the next at the end of the study } \\
\text { period ( } 2171 \text { in this study). }\end{array}$ & $\mathrm{MgC} \mathrm{ha}{ }^{-1}$ \\
\hline
\end{tabular}

proxy for landscape scale dynamics. Understanding these dynamics in the Northeast would inform similar research in other regions of the United States as well as ongoing work in Europe and beyond (e.g., see Zanchi et al., 2012). We hypothesize that if bioenergy harvests are distributed over large spatial and temporal scales, the net landscape forest $C$ storage will decrease and net $\mathrm{C}$ emissions will increase. This will result in a lower (positive) net cumulative $\mathrm{C}$ flux over the landscape compared to non-bioenergy harvests.

\section{Carbon debt and dividend from bioenergy harvests}

In the short term, bioenergy is not as efficient as fossil fuels in generating energy due to lower heat content, which results in higher immediate emissions (Zanchi et al., 2012). Indirect emissions from harvesting, processing, and transporting wood biomass are less than $5 \%$ of the combustion emissions, while they can be 3.5-14\% for coal and 15-25\% for natural gas (Manomet Center for Conservation Sciences, 2010; Hudiburg et al., 2011; Routa et al., 2011). Although the lower indirect emissions (see definition in Table 1) for bioenergy compresses the difference in overall emissions from bioenergy compared to fossil fuels, this does not compensate for the decreased forest $\mathrm{C}$ stocks (i.e., storage) from bioenergy harvesting (Schulze et al., 2012; Zanchi et al., 2012). Therefore, in the short-term bioenergy results in net emissions, or a net flux to the atmosphere (Cherubini et al., 2011; Routa et al., 2011; Domke et al., 2012; Mika \& Keeton, 2013). The near-term of one to several decades may be particularly important for stabilizing atmospheric greenhouse gases, beyond which some scientists have suggested there may be irreversible disruption of the planet's climate system even if atmospheric concentrations of greenhouse gases ultimately decrease (Solomon et al. 2009).

The frequency and intensity of harvests affect the residual landscape $\mathrm{C}$ and how long it takes to recover that $\mathrm{C}$ either through growth and regeneration or substitution effects (Eriksson et al., 2007; Malmsheimer et al., 2008; Nunery \& Keeton, 2010). The time-lag to reach C-neutrality can vary from 40 to 150 years and depends on the growth rate of the stand (Schlamadinger \& Marland, 1999). In this study, only with replanting and high growth rates of $1.5-3 \mathrm{Mg} \mathrm{C}^{-1} \mathrm{yr}^{-1}$ was it possible to sequester more $C$ using active management than with no management (Schlamadinger \& Marland, 1999). However, Schlamadinger \& Marland (1999) investigated clearcutting scenarios with replanting, while in the Northeast, partial harvesting systems are the dominant practices and regeneration is mostly natural. Assessing the effect on net landscape C 'flux' (i.e., net change; Table 1) using partial harvesting or a combination of treatments may yield different results.

Some researchers argue that demand for bioenergy may result in intensification of harvests (Briedis et al., 2011a; Zanchi et al., 2012; Peckham \& Gower, 2013). Although volume for bioenergy can come from thinning operations, residues, mill waste, urban tree trimmings/ removals, and bioenergy plantations (Lattimore et al., 2009), in the US Northeast it is most often the dead 
wood, tree tops, and low grade, poorly formed stems (or cull) that are removed for bioenergy (Briedis et al., 2011b). The practice of whole-tree harvesting, where both merchantable and unmerchantable portions of a tree are removed, including tops and limbs (Johnson \& Curtis, 2001), has been on the rise due to increasing demand for bioenergy (Briedis et al., 2011a). Demand in the bioenergy market increases the economic feasibility of removing unmerchantable material (Briedis et al., 2011a; Lippke et al., 2011). A recent field study found that whole-tree bioenergy operations resulted in significantly greater removals of snags and a trend toward reducing downed coarse woody debris (DCWD; not including standing dead trees; Mika \& Keeton, 2013). In addition, whole-tree harvesting decreased aboveground live tree basal area by an average of 3\% more compared to non-whole-tree harvested sites (A. Mika and W. Keeton, unpublished data). If bioenergy harvests result in increased removals of live biomass or residues (Zanchi et al., 2012), this may reduce average landscape $\mathrm{C}$ storage and increase atmospheric $\mathrm{CO}_{2}$, even with fossil fuel offsets (McKechnie et al., 2011; Gunn et al., 2012).

Despite the potential for greater net $\mathrm{C}$ emissions associated with intensified harvesting, some bioenergy harvesting practices, such as stand improvement cuttings, removing low grade material, have the potential to improve stand stocking and residual tree quality (Hoover \& Stout, 2007). These practices may increase merchantable volumes and C sequestration rates (Hoover \& Stout, 2007). Some researchers have argued that more intensive management results in the greatest $C$ benefit due to substitution effects, such as displacing fossil fuels with wood bioenergy or substituting more emissionsintense building materials with wood (Eriksson et al., 2007; Davis et al., 2009; Routa et al., 2011). However, their conclusion was based on keeping forest $\mathrm{C}$ stocks intact for 4 extra years in the intensive management scenario (Eriksson et al., 2007). In fact, the authors recommend short rotations when the forest management goal is to generate both wood products and bioenergy (Eriksson et al., 2007). In contrast, other researchers argue that less intense harvesting results in a net $\mathrm{C}$ benefit (Harmon \& Marks, 2002; Swanson, 2009; Nunery \& Keeton, 2010), although only Harmon \& Marks (2002) included bioenergy harvesting. In a simulation study of Scots pine (Pinus sylvestris) and Norway spruce (Picea abies) in a boreal forest, increasing the minimum basal area required before a harvest occurred reduced indirect $C$ emissions from operations, depending on thinning intensity, stand density, species, and site conditions (Alam et al., 2012).

Finally, not only does management impact net C fluxes, but the end-use of the harvested wood, the source of wood (e.g., live trees, tree tops, slash), and type of fossil fuel displaced also impact the net C emissions from bioenergy (Eriksson et al., 2007; Sathre \& Gustavsson, 2011). For example, offsetting a relatively low-emissions fossil fuel such as natural gas with bioenergy may increase the time-lag to C-neutrality compared to coal (Eriksson et al., 2007; Sathre \& Gustavsson, 2011). This is because the energy derived from combustion of natural gas is $55 \mathrm{MJ} \mathrm{kg}^{-1}$ of fuel, while it is much lower $\left(27 \mathrm{MJ} \mathrm{kg}^{-1}\right.$ ) for coal and bioenergy (8-20 MJ kg ${ }^{-1}$, depending on moisture content) (Demirbas, 2001). Comprehensive accounting for the net C budget effects of bioenergy harvesting is further complicated by spatial and temporal dynamics of forest management. Often, researchers simulate a single rotation, which can change the fundamental conclusions about the C-neutrality of bioenergy (Holtsmark, 2013). To produce an unbiased analysis, the temporal fluctuations in $\mathrm{C}$ stored in forest biomass and wood products as well as emissions have to be taken into account (Helin et al., 2013). In our study, we addressed this research gap by evaluating the net $C$ fluxes from bioenergy harvest staggered temporally and spatially over the landscape.

\section{Landscape analysis framework}

The spatial scale at which C-accounting is conducted may influence conclusions regarding net $\mathrm{C}$ flux, such as whether a stand or landscape is a net $C$ source or sink (Harmon, 2001). For example, at the stand level it may appear that $\mathrm{C}$ is being emitted through decomposition of dead wood, but averaged over the landscape, C stores in dead pools may be stable or increasing (Harmon, 2001). A more holistic picture of the $C$ impacts of harvesting requires comparing the average cumulative storage of $\mathrm{C}$ over time in managed forests (Cherubini et al., 2011) over multiple stands and harvest rotations (Zanchi et al., 2012; Holtsmark, 2013). Although some argue that the net $\mathrm{C}$ fluxes over the landscape scale should be averaged over a specified period of time, such as one rotation period (Harmon, 2001), the impact of bioenergy harvests on forest $\mathrm{C}$ stocks at any given time is also important (Gunn et al., 2012). If bioenergy harvesting results in a lower $\mathrm{C}$ equilibrium storage condition over the landscape then the absolute forest $\mathrm{C}$ stocks indicate additional $\mathrm{CO}_{2}$ in the atmosphere, regardless of the baseline (Gunn et al., 2012). Comparing to a non-bioenergy harvest scenario as the baseline reveals exactly how much additional $\mathrm{C}$ has been released to the atmosphere. If net $C$ fluxes are averaged over the study period, harvesting multiple stands with different entry cycles may result in no change in net $C$ flux when averaged over the entire landscape (Mika \& Keeton, 2013). 
Most studies examining bioenergy harvesting effects on long-term net $\mathrm{C}$ fluxes have used sophisticated forest $\mathrm{C}$ models, but are limited by overly simplistic assumptions about C-neutrality of bioenergy and do not incorporate indirect emissions in a full life-cycle analysis, as pointed out by McKechnie et al. (2011). For example, modeling exercises often schedule harvests simultaneously, resulting in a recurring increase in $\mathrm{C}$ during growth then a sharp drop during harvest (e.g., see Manomet Center for Conservation Sciences, 2010). They also often model one stand, rotation system, one harvest, or simultaneous harvests occurring over multiple stands, all of which illustrate short-term net emissions of $C$ followed by a recovery (e.g., see Cherubini et al., 2011; Zanchi et al., 2012; Holtsmark, 2013). In this study, our objectives were to evaluate the net $\mathrm{C}$ flux from bioenergy harvests when partial harvests are staggered over the landscape, and comparing the net $C$ fluxes of (i) no management; (ii) non-bioenergy harvests; and (iii) bioenergy harvest scenarios. We used a life-cycle $\mathrm{C}$-accounting framework to assess the potential $\mathrm{C}$ emissions from intensified bioenergy harvests in an effort to inform policy.

\section{Materials and methods}

\section{Study area and site selection criteria}

The study area encompasses the northern hardwood-conifer forest of the northeastern US, including portions of Maine, New Hampshire, New York, and Vermont. Dominant late-successional species include Acer saccharum (sugar maple), Fagus grandifolia (American beech), Tsuga canadensis (eastern hemlock), and Betula alleghaniensis (yellow birch). We selected forested USDA Forest Service Forest Inventory and Analysis (FIA) plots of the maple/beech/birch forest-group type, which is the most common in the northern forest region and has the potential to be harvested for both conventional products and bioenergy.

We partially constrained variability by retaining stands of natural origin (no plantations) and excluding inoperable sites (wetlands; $>50 \%$ slopes; $>723 \mathrm{~m}$ elevation). We used the FIA annual inventory reports to stratify FIA plots inventoried in 2009/2010 (termed 'sites' in this article). We selected FIA plots with various inventoried basal areas to compare differing starting conditions. We also included the site index when it was available to retain some variability in site productivity between sites. We further stratified sites by eco-subregion in the M211 series (Bailey, 2004) of Adirondack/New England Mixed Forest-Coniferous Forest-Alpine Meadow. To obtain a representative sample that reflected the age distribution in the study area, we randomly excluded sites from some age classes based on FIA summary inventory tables (using Table 12 in Smith et al., 2009). The stratification was applied to the 3306 sites in the four northeastern states and resulted in a final sample of 362 sites with 148 in Maine, 70 in New Hampshire, 56 in New York, and 88 sites in Vermont.

\section{Forest growth model}

We used the northeastern variant of the Forest Vegetation Simulator (FVS-NE) to model the growth and harvests of stands over time. FVS is an empirical individual tree-based forest growth simulator (Crookston \& Dixon, 2005) that has been used in the forestry industry for almost 40 years. It is a distance-independent and can be used for both even and uneven-aged stands with simple to mixed species compositions (Crookston \& Dixon, 2005). NE-TWIGS, an individual tree growth and mortality model used by FVS-NE, has been shown to have 77-99\% efficiency in short-term projections of tolerant hardwood stands in Ontario (Bankowski et al., 1996). However, for higher accuracy, regional regeneration data need to be adjusted based on field data and input by the user for studies spanning greater than 20 years (Bankowski et al., 1996).

Forest Vegetation Simulator (FVS) was chosen for its flexibility in simulating types and timing of harvests, particularly selection systems, availability of a variant calibrated for the Northeast, and compatibility with FIA data (Ray et al., 2009a). Harvests can be scheduled conditionally or by year and multiple simulated harvests can be implemented in one model run, with the ability to target specific size classes or species (Crookston \& Dixon, 2005). The model is typically run at 5-10 year time steps for any period of time (Crookston \& Dixon, 2005). The user can adjust regeneration inputs, slash management, fuel treatment, and fertilizer, among other options (Crookston \& Dixon, 2005). Outputs include various stand structure attributes including $\mathrm{C}$ stocks in aboveground and belowground live and dead pools as well as $\mathrm{C}$ transferred to and persisting in wood products.

We did not include soil C, environmental stressors, natural disturbances, climate change, or future increases in atmospheric $\mathrm{CO}_{2}$ concentrations in our model predictions. We acknowledge these factors are likely to affect $\mathrm{C}$ dynamics in northeastern forests (Ollinger et al., 2008) and change future forest productivity and species compositions (Pastor \& Post, 1986; Ollinger et al., 2002; Wamelink et al., 2009; Xu et al., 2009). The focus of our study was the relative difference among management scenarios as a function of treatment alone, holding climate and disturbance constant, an approach consistent with other modeling studies (Eriksson et al., 2007; Nunery \& Keeton, 2010). Furthermore, FVS calculates coarse root biomass stocks as a ratio to aboveground biomass; however, it does not include soil $\mathrm{C}$ because sites are highly variable and have different responses to management regimes (Schwenk et al., 2012). Hence, we chose not to include belowground $C$ because the soil and fine roots pools are not estimated by FVS. Had we assumed soil $\mathrm{C}$ fluxes to vary positively with management intensity, the relative contrasts we found among scenarios would likely have been accentuated further (Nave et al., 2010; Zummo \& Friedland, 2011).

\section{Regeneration parameters}

Forest Vegetation Simulator (FVS) is highly sensitive to regeneration (Ray et al., 2009a; Nunery \& Keeton, 2010). Although FVS-NE automatically sprouts some hardwood species from 
stumps, the variant does not have a full regeneration model and the user has to input natural regeneration parameters (Ray et al., 2009a). Therefore, following Nunery \& Keeton (2010) we turned off the sprouting option and defined natural regeneration parameters for each harvest scenario (Table 2).

We simulated natural regeneration of the most dominant species based on the average basal area of species present at all 362 sites. The abundance and type of species projected to regenerate after a simulated harvest depended on their shade tolerance as well as the light conditions created by the type and intensity of harvest. The regeneration inputs were generated using a spreadsheet tool developed by C.D. Kerchner and W.S. Keeton (unpublished Data), using field data presented in Nunery \& Keeton (2010) and Leak (2005). Background regeneration of intermediate and shade-tolerant species was simulated at 10 year intervals, while specific post-harvest regeneration was linked to its harvest scenario minus the background regeneration. This procedure avoided double inputs of regeneration following harvests.

\section{Harvest scenarios}

The general categories of harvest scenarios included the following: (i) a 'No Management' scenario; (ii) a non-bioenergy harvest; and (iii) a variety of bioenergy harvests. The active management scenarios (both non-bioenergy and bioenergy) integrated three silvicultural prescriptions commonly employed in the northeastern US (Table 3), based on Leak et al. (1987) and Seymour et al. (2002). The proportion of sites receiving each silvicultural treatment that made up the non-bioenergy scenario was an approximate representation of the frequency with which these systems are employed in practice. We used a negative exponential distribution to approximate the proportion of each silvicultural treatment in practice. We randomly assigned single-tree selection, shelterwood, or clearcut to $67 \%, 24 \%$, or $9 \%$ of the sites, respectively.

Both the shelterwood and clearcut harvests involved a thinning to a residual basal area of $14.0 \mathrm{~m}^{2} \mathrm{ha}^{-1}$ any time the stand attained full stocking $\left(27.55 \mathrm{~m}^{2} \mathrm{ha}^{-1}\right)$. We imposed a constraint of no thinning 30 years before the regeneration harvest to prevent a clustering of treatments in time. The final removal cut in the shelterwood harvest was implemented 10 years after the regeneration harvest. We ran FVS-NE on 5-year time steps for better temporal resolution of projected $\mathrm{C}$ in various pools. The length of the study was 160 years to allow for at least two full cycles of harvest in the high frequency even-aged management scenario (Table 3).

The simulated harvests were staggered temporally so that not all harvests occurred simultaneously, which would result in a drop of $C$ (from decrease in forest $C$ and increase in emissions), with a subsequent recovery of $C$ through regrowth and fossil fuel offsets. Instead, using the projected growth of each site under a 'No Management' scenario we determined when each site is predicted to reach full stocking and would be ready for harvest. We randomly divided each group of sites ready to be harvested at each 5-year cycle into five groups. For example, of the 45 sites ready to be harvested in 2016, only 9 were harvested in 2016; the remainder was harvested in 2021, 2026, 2031, and 2036. This allowed us to more realistically mimic the temporal complexity of harvests as they occur in practice.

Bioenergy harvests were simulated using two levels of bioenergy harvesting intensification with and without residual basal area limits. This was done to simulate minimum stocking thresholds recommended by silvicultural guides (Leak et al., 1987) and required by some Northeast states through heavy cutting laws and best management practices. Removing the residual basal area limit illustrates the potential outcomes of avoiding minimum stocking requirements, such as through the

Table 2 Regeneration inputs by species and harvest scenario (seedlings ha ${ }^{-1}$ ). The seedlings were naturally regenerated with $80 \%$ survival rate, uniform distribution, and an average height of $61 \mathrm{~cm}$. The background regeneration occurred every 10 years; the actual inputs for post-harvest regeneration were those in the table minus the background regeneration. Regeneration values for bioenergy harvests are for the mean bioenergy removal; regeneration for the 75th percentile removal and 'Bioenergy Intensification' scenarios were increased further

\begin{tabular}{|c|c|c|c|c|c|c|c|c|}
\hline Species & $\begin{array}{l}\text { Dominance based } \\
\text { on Average } \\
\text { Basal Area (\%) }\end{array}$ & Back-ground & $\begin{array}{l}\text { Single-Tree } \\
\text { Selection }\end{array}$ & Shelter-wood & Clearcut & $\begin{array}{l}\text { Bioenergy } \\
\text { single-tree } \\
\text { selection }\end{array}$ & $\begin{array}{l}\text { Bioenergy } \\
\text { shelterwood }\end{array}$ & $\begin{array}{l}\text { Bioenergy } \\
\text { clearcut }\end{array}$ \\
\hline Acer rubrum & 17 & 9 & 28 & 74 & 93 & 31 & 75 & 93 \\
\hline Acer saccharum & 27 & 83 & 148 & 221 & 184 & 165 & 223 & 184 \\
\hline Pinus strobus & 2 & 0 & 8 & 62 & 155 & 9 & 62 & 155 \\
\hline Abies balsamea & 5 & 16 & 29 & 43 & 36 & 32 & 44 & 36 \\
\hline Tsuga canadensis & 5 & 15 & 27 & 41 & 34 & 30 & 41 & 34 \\
\hline Picea rubens & 5 & 16 & 29 & 43 & 36 & 32 & 44 & 36 \\
\hline Betula alleghaniensis & 14 & 8 & 24 & 63 & 79 & 26 & 63 & 79 \\
\hline Thuja occidentalis & 1 & 2 & 4 & 6 & 5 & 4 & 6 & 5 \\
\hline Fagus grandifolia & 15 & 47 & 83 & 125 & 104 & 93 & 126 & 104 \\
\hline Betula papyrifera & 4 & 0 & 12 & 98 & 245 & 14 & 99 & 245 \\
\hline Quercus rubra & 2 & 1 & 3 & 8 & 10 & 4 & 8 & 10 \\
\hline Fraxinus americana & 3 & 2 & 5 & 14 & 18 & 6 & 14 & 18 \\
\hline Total & 100 & 200 & 400 & 800 & 1000 & 446 & 806 & 1000 \\
\hline
\end{tabular}


Table 3 Description and parameters for the non-bioenergy and bioenergy active management scenarios used in the Forest Vegetation Simulator

\begin{tabular}{|c|c|c|c|c|c|c|}
\hline & \multicolumn{3}{|c|}{ Non-bioenergy management scenario } & \multicolumn{3}{|c|}{ Bioenergy management scenario } \\
\hline & Single-tree selection & Shelterwood & Clearcut & Single-tree selection & Shelterwood & Clear-cut \\
\hline $\begin{array}{l}\text { Nunery \& Keeton } \\
\text { (2010) scenario }\end{array}$ & ITS_HighLow & Shelterwood_High & Clearcut_Low & & & \\
\hline Frequency & $\begin{array}{l}\text { Low } \\
\text { (30 years) }\end{array}$ & $\begin{array}{l}\text { High } \\
\text { (80 years) }\end{array}$ & $\begin{array}{l}\text { Low } \\
\text { (120 years) }\end{array}$ & $\begin{array}{l}\text { Low } \\
\text { (30 years) }\end{array}$ & $\begin{array}{l}\text { High } \\
\text { (80 years) }\end{array}$ & $\begin{array}{l}\text { Low } \\
\text { (120 years) }\end{array}$ \\
\hline $\begin{array}{l}\text { Structural } \\
\text { Retention }\end{array}$ & High & High & Low & High & High & Low \\
\hline q-factor & 1.3 & - & - & 1.3 & - & - \\
\hline $\begin{array}{l}\text { Residual BA } \\
\left(\mathrm{m}^{2} \mathrm{ha}^{-1}\right)\end{array}$ & 19.00 & 14.00 & 0.00 & 18.43 & 13.58 & 0.00 \\
\hline $\begin{array}{l}\text { Min. DBH } \\
\text { class }(\mathrm{cm})\end{array}$ & 5 & 5 & 5 & 0 & 0 & 0 \\
\hline $\begin{array}{l}\text { Max. DBH } \\
\text { class }(\mathrm{cm})\end{array}$ & 61 & - & - & 61 & - & - \\
\hline $\begin{array}{l}\text { DBH class } \\
\text { width }(\mathrm{cm})\end{array}$ & 5 & - & - & 5 & - & - \\
\hline $\begin{array}{l}\text { Number } \\
\text { of legacy } \\
\text { trees (per ha) }\end{array}$ & 12 & 6 & 0 & 12 & 6 & 0 \\
\hline $\begin{array}{l}\text { Average } \\
\text { diameter } \\
\text { legacy } \\
\text { trees }(\mathrm{cm})\end{array}$ & 41 & 15 & 0 & 41 & 15 & 0 \\
\hline $\begin{array}{l}\text { Slash left } \\
\text { on site? }\end{array}$ & Yes & Yes & No & No & No & No \\
\hline $\begin{array}{l}\text { Proportion of } \\
\text { landscape } \\
\text { receiving } \\
\text { treatment }(\%)\end{array}$ & 67 & 24 & 9 & 67 & 24 & 9 \\
\hline
\end{tabular}

issuance of heavy cut permits. Although this scenario may have only limited geographic applicability, it allows for the differentiation of potential intensifications of bioenergy. For all bioenergy harvests, the minimum tree size harvested was decreased from 5 to $0 \mathrm{~cm}$ (i.e., no minimum tree size limit) The slash (i.e., unmerchantable tops) was removed in the single-tree selection and shelterwood bioenergy harvests, but was retained in the non-bioenergy scenarios.

The bioenergy harvest scenarios had additional volume removed on top of that harvested in the non-bioenergy scenario (Table 3). Poorly formed or 'cull' trees, smaller stems, tree tops, and dead wood that is considered waste or residue is typically used for bioenergy applications, such as chips or pellets (Briedis et al., 2011b). Hence, in our study, bioenergy harvests were simulated as whole-tree removal and residual basal areas were decreased (relative to non-bioenergy) based on field data in the study region (A. Mika and W. Keeton, unpublished data). On the basis of this field data, we calibrated the bioenergy harvests to match the mean and 75th percentile intensities, which reflects two different levels of bioenergy harvest intensification. This resulted in an additional reduction in residual basal area of $3 \%$ and $12.5 \%$, respectively, for bioenergy harvests relative to the non-bioenergy scenario (A. Mika and W. Keeton, unpublished data). The 75th percentile intensification scenario decreased the residual basal area from 18.43 to $16.62 \mathrm{~m}^{2} \mathrm{ha}^{-1}$ for bioenergy single-tree selection harvests and from 13.58 to $12.24 \mathrm{~m}^{2} \mathrm{ha}^{-1}$ for bioenergy shelterwood harvests. All of the additional harvested volume (relative to the non-bioenergy harvest) was allocated to bioenergy, while the remainder went to wood products or residues. Hence, in most simulations, the amount of wood products was the same for bioenergy and non-bioenergy harvests, except in extreme cases where the additional volume removal in a bioenergy harvest pushed the stocking so low that the subsequent harvest yielded fewer wood products (see Discussion).

Directly combusting bioenergy for heating has a $20 \%$ loss (i.e., $80 \%$ efficiency), while electricity generation has a much lower efficiency of 20-40\% (Demirbas, 2001). Therefore, the additional volume harvested and slash was allocated to bioenergy for electricity or thermal, with the regional Northeast eGRID (Rothschild et al., 2009) or natural gas as the reference fuel mix, respectively. We assumed $30 \%$ efficiency for electricity and $80 \%$ efficiency for thermal (Demirbas, 2001). The emissions for the Northeast eGRID NEWE sub-region were $0.11 \mathrm{Mg}$ 
$\mathrm{CO}_{2} \mathrm{e}\left(\mathrm{CO}_{2}\right.$-equivalents) per GJ (Rothschild et al., 2009) and $0.08 \mathrm{Mg} \mathrm{CO} \mathrm{CO}_{2} \mathrm{e} / \mathrm{GJ}$ for natural gas used in thermal applications (California Air Resources Board, 2010). Assuming that 50\% of the mass of wood is C (Birdsey, 1992), we calculated that the corresponding emissions from bioenergy were 0.76 and $0.29 \mathrm{Mg} \mathrm{CO}_{2} \mathrm{e} / \mathrm{GJ}$ for electricity and thermal, respectively. We applied the bioenergy harvests to $25 \%, 50 \%$, or $100 \%$ of the stands (named BIO25, BIO50, and BIO100 scenarios, respectively) with the remainder receiving the non-bioenergy harvest. Stands that received the bioenergy harvest in the BIO25 and BIO 50 scenarios were those that had the largest percentage of class 3 (cull) trees relative to class 2 (acceptable) and class 1 (desirable) trees.

To ensure that the residual basal area thresholds did not drive our results, we also tested the effect of removing the residual basal area limit on net cumulative $C$ fluxes by modeling a scenario called 'Bioenergy Intensification.' For the first entry cycle of the single-tree selection treatment, the 'Bioenergy Intensification' scenario involved the removal of an equivalent amount as the \% reduction in basal area for the most intensive bioenergy harvests with residual basal area limits. For shelterwood harvests in this scenario, we reduced the residual basal area to $20 \mathrm{ft}^{2}$ acre or $4.59 \mathrm{~m}^{2} \mathrm{ha}^{-1}$, a level representing the minimum as practiced in the Northeast.

\section{Net carbon fluxes and carbon neutrality}

Fluxes, including $C$ sequestration and storage minus emissions (Fig. 1), were calculated for each 5-year time step and averaged across all stands. Carbon in forest stands and transferred to wood products was calculated using the Fire and Fuels Extension in FVS-NE. Allometric equations developed by Jenkins et al. (2003) were chosen to calculate forest $C$ in aboveground live, aboveground dead, and downed dead wood because tree height data, required by other allometric equations, was not consistently available for all FIA tree measurements. The Jenkins et al. (2003) equations have also been widely used by other studies (e.g., Fredeen et al., 2005; Keeton, 2006; Lamsal et al., 2011; Mika \& Keeton, 2013). FVS-NE tracks the C in wood products throughout their life cycle using the methodology developed by Smith et al. (2006). This includes the amount and residency period of $\mathrm{C}$ stored in wood products, transferred to landfills, emitted with energy capture at wood processing mills, and emitted from processing without energy capture. The percentage of sawlogs and pulpwood still in use after 100 years is based on region and divided into hardwood and softwood. For example, in the Northeast, an average fraction of 0.095 of softwood sawlogs is in use after 100 years (Smith et al., 2006). Finally, direct and indirect emissions from energy generated from bioenergy and that from fossil fuel offsets (i.e., avoided fossil fuel emissions) as well as indirect emissions (Table 1; Fig. 1) from harvesting wood products were calculated according to Mika \& Keeton (2013). We chose to exclude wood product substitution from our analysis and focused on the $\mathrm{CO}_{2}$ emissions from bioenergy and the fossil fuel offsets. The fossil fuel emissions from energy captured during the processing of wood products (and associated indirect emissions from the extraction and processing of those fossil fuels) were also not relevant to this study. However, the amount of wood products was usually the same for paired stands receiving

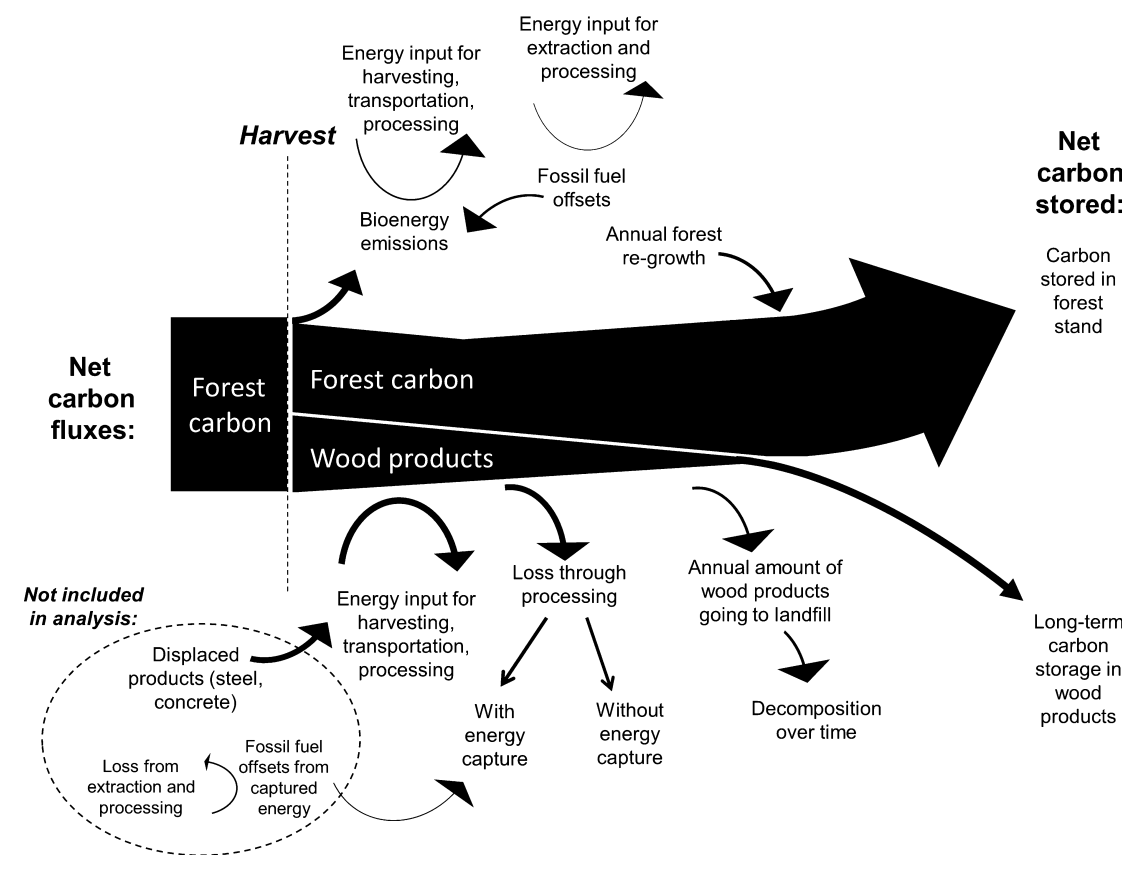

Fig. 1 Sankey diagram showing the net carbon fluxes included in this study. The stocks and flows are proportional to the size of the pool or emission of carbon. Excluded sources include the following: displaced building products such as steel and concrete; fossil fuel offsets from captured energy during the processing of wood products; and associated loss from extraction and processing of the fossil fuel offsets from captured energy. 
either the bioenergy or non-bioenergy harvests (since the additional volume went to bioenergy). Therefore, since the comparison is relative, this likely would not have affected our results, but would have complicated the analysis further.

We calculated the total 160-year and annual average net cumulative $C$ flux (see Table 1 for definitions) over the simulation period to evaluate the temporal dynamics of net carbon fluxes between scenarios, particularly to contrast bioenergy and non-bioenergy scenarios. We also assessed whether a positive net cumulative flux was reached at any point during the 160-year duration of the study for an individual stand or for the total landscape average. We compared these net cumulative and average fluxes among scenarios as well as relative to the no management and non-bioenergy scenarios.

\section{Statistical and sensitivity analysis}

We used JMP 9.0.0 for Windows (SAS Institute Inc, 2010) to compare differences in $\mathrm{C}$ pools and net $\mathrm{C}$ fluxes, using $\alpha=0.05$ as the statistically significant level. The single-factor ANOvA with post hoc Tukey-Kramer HSD pair-wise comparisons tested for differences between management scenarios. We compared both the average $C$ stored/emitted in various pools as well as the percent difference (Westerling et al., 2006; Mika \& Keeton, 2013) in aboveground forest C pools from 2011 to 2171. We used a paired $t$-test to test for differences between net cumulative fluxes from bioenergy harvests where bioenergy was used for electricity generation or heating.

We performed a multivariate analysis to evaluate which factors may contribute the most to net cumulative $\mathrm{C}$ flux from bioenergy harvests, using a classification and regression tree (CART). CART is a robust nonparametric statistical tool that partitions variance in a dependent variable based on either categorical or numeric independent variables (De'ath \& Fabricius, 2000). It is useful in ecological applications because it is able to assess nonlinear relationships, missing data, and high-order interactions (De'ath \& Fabricius, 2000). CART allows for a better understanding of the relative predictive power of multiple independent variables (De'ath \& Fabricius, 2000; Keeton \& Franklin, 2005; Keeton et al., 2007). For our study, we used CART to determine which factors explained the largest amount of variance in net C fluxes from all 362 stands using the BIO100 results. The independent variables included harvest parameters (harvest type and harvest group), stand characteristics (age, aspect, slope, elevation, forest type, ecoregion, percent cull, starting basal area, initial biomass, and site index; Table 4). Harvest year was strongly correlated with starting live biomass $(r=0.71)$; however, starting live biomass was not correlated with starting basal area $(r=0.14)$. Therefore, harvest year was removed from further analysis, but harvest group was kept as a variable that reflected timing of harvest. We validated the most parsimonious tree using $75 \%$ of the data to train and $25 \%$ to validate the model.

To test whether assigning the bioenergy harvest to stands with highest percentage of cull trees affected our results, we randomly assigned bioenergy harvests to $50 \%$ of the stands and re-ran the BIO50 scenario. We also assessed the net cumulative $C$ fluxes of bioenergy harvests if additional slash was
Table 4 Independent variables used in the Classification and Regression Tree (CART) multivariable analysis, their respective levels, of number of sites for each classification

\begin{tabular}{|c|c|c|}
\hline Variable & Levels & $\begin{array}{l}\text { Number } \\
\text { of sites }\end{array}$ \\
\hline \multirow[t]{3}{*}{ Harvest type } & Single-tree selection & 242 \\
\hline & Shelterwood & 87 \\
\hline & Clearcut & 33 \\
\hline \multirow[t]{5}{*}{$\begin{array}{l}\text { Harvest } \\
\text { group }\end{array}$} & $\begin{array}{l}\text { Harvested } \\
\text { immediately }\end{array}$ & 78 \\
\hline & $\begin{array}{l}\text { Harvested } \\
\text { after } 5 \text { years }\end{array}$ & 76 \\
\hline & $\begin{array}{l}\text { Harvested } \\
\text { after } 10 \text { years }\end{array}$ & 71 \\
\hline & $\begin{array}{l}\text { Harvested } \\
\text { after } 15 \text { years }\end{array}$ & 70 \\
\hline & $\begin{array}{l}\text { Harvested } \\
\text { after } 20 \text { years }\end{array}$ & 67 \\
\hline Age & Continuous & 362 \\
\hline Aspect & Continuous & 362 \\
\hline Slope & Continuous & 362 \\
\hline $\begin{array}{l}\text { Elevation } \\
\text { (feet) }\end{array}$ & Continuous & 362 \\
\hline \multirow[t]{4}{*}{ Forest type } & $\begin{array}{l}\text { Sugar maple/ } \\
\text { beech/yellow } \\
\text { birch (801) }\end{array}$ & 287 \\
\hline & Black cherry (802) & 3 \\
\hline & $\begin{array}{l}\text { Hard maple/ } \\
\text { basswood (805) }\end{array}$ & 1 \\
\hline & Red maple/upland (809) & 71 \\
\hline \multirow[t]{21}{*}{ Ecoregion } & M211Aa & 17 \\
\hline & M211Ab & 42 \\
\hline & M211Ac & 30 \\
\hline & M211Ad & 16 \\
\hline & M211Ae & 35 \\
\hline & M211Af & 33 \\
\hline & M211Ag & 19 \\
\hline & M211Ba & 29 \\
\hline & $\mathrm{M} 211 \mathrm{Bb}$ & 14 \\
\hline & M211Bc & 15 \\
\hline & M211Bd & 8 \\
\hline & M211Ca & 22 \\
\hline & $\mathrm{M} 211 \mathrm{Cb}$ & 5 \\
\hline & $\mathrm{M} 211 \mathrm{Cc}$ & 6 \\
\hline & M211Cd & 15 \\
\hline & M211Da & 7 \\
\hline & $\mathrm{M} 211 \mathrm{Db}$ & 12 \\
\hline & M211Dc & 17 \\
\hline & M211Dd & 10 \\
\hline & M211De & 6 \\
\hline & M211Df & 4 \\
\hline Percent cull & Continuous & 362 \\
\hline Start BA & Continuous & 363 \\
\hline $\begin{array}{l}\text { Start live } \\
\text { biomass }\end{array}$ & Continuous & 364 \\
\hline $\begin{array}{l}\text { Site index } \\
\text { (sugar maple) }\end{array}$ & Continuous & 364 \\
\hline
\end{tabular}


removed from thinnings between the shelterwood and clearcut regeneration harvests.

\section{Results}

Changes in carbon stocks and cumulative emissions at the individual stand level

Compared to net $\mathrm{C}$ flux from non-bioenergy harvests, of the 362 stands only 99 had a projected positive net flux in any given year (i.e., not cumulative) when harvested for bioenergy. The simulated BIO25, BIO50, and BIO100 scenarios had smaller aboveground forest $\mathrm{C}$ pools (annual average stocks of 83.34, 81.28, and $77.47 \mathrm{Mg}$ $\mathrm{C} \mathrm{ha}{ }^{-1}$, respectively) and wood products (annual average stock of 21.32, 21.23, and $21.02 \mathrm{Mg} \mathrm{C}^{-1}$, respectively) than non-bioenergy harvests (annual average stock of $85.29 \mathrm{Mg} \mathrm{C} \mathrm{ha}^{-1}$ in aboveground forest pools and 21.42 in wood products).

Although the projected annual indirect emissions from harvesting, processing, and transporting wood products were $0.12-0.54 \mathrm{Mg} \mathrm{C} \mathrm{ha}{ }^{-1}$ lower for bioenergy harvests than for non-bioenergy harvests, the bioenergy harvests had additional emissions from the combustion of bioenergy. For the BIO25, BIO50, and BIO100 scenarios, these were additional annual emissions of $0.63,1.27$, and $2.54 \mathrm{Mg} \mathrm{C} \mathrm{ha}^{-1}$, respectively, from bioenergy combustion. Even with the inclusion of fossil fuel offsets (0.10-0.39 $\left.\mathrm{Mg} \mathrm{C} \mathrm{ha-1} \mathrm{yr}^{-1}\right)$, this resulted in net emissions in any given year compared to non-bioenergy harvests. The average total storage for BIO100 was 57.93 while it was $67.76 \mathrm{Mg} \mathrm{C}$ ha $^{-1}$ for non-bioenergy harvests. Averaged over 160 years, all but three stands in the BIO100 had net positive emissions (i.e., net flux to the atmosphere) relative to non-bioenergy.

We then calculated the net cumulative $C$ fluxes for each stand at the end of the 160-year simulation period (Fig. 2). When all stands were harvested as bioenergy (i.e., the BIO100 scenario) for electricity generation, 64 stands resulted in a negative net cumulative $C$ flux and 298 yielded a net $C$ benefit (positive net cumulative $C$ flux). Overall, the net cumulative $\mathrm{C}$ flux ranged from -73.78 to $137.81 \mathrm{Mg} \mathrm{C} \mathrm{ha}^{-1}$. In comparison, the No Management' had an average of $158.60 \mathrm{Mg} \mathrm{C}$ ha $^{-1}$ (range of $54.06-293.39 \mathrm{Mg} \mathrm{C} \mathrm{ha}{ }^{-1}$ ) net cumulative C flux at the end of the simulation period, or $0.99 \mathrm{Mg}$ $\mathrm{C} \mathrm{ha}{ }^{-1}$ stored per year. The majority of this, $0.80 \mathrm{Mg}$ $\mathrm{C} \mathrm{ha}^{-1}$, was sequestered by live trees. The net $\mathrm{C}$ accumulation based on the 'No Management' scenario far surpassed that of the active management scenarios (single-factor ANOVA; $P<0.0001)$. Using percent difference (change from 2011 to 2171) of $C$ in live tree and standing dead tree showed that only the active management scenarios were different from the 'No Management' $(P<0.0001)$. The 'No Management' scenario also showed an increase in cumulative $C$ storage in the DCWD by the end of the simulation period, increasing from 4.58 to $12.70 \mathrm{Mg} \mathrm{C} \mathrm{ha}{ }^{-1}$. The further statistical analyses focused on comparing the active management scenarios (with and without bioenergy harvest).

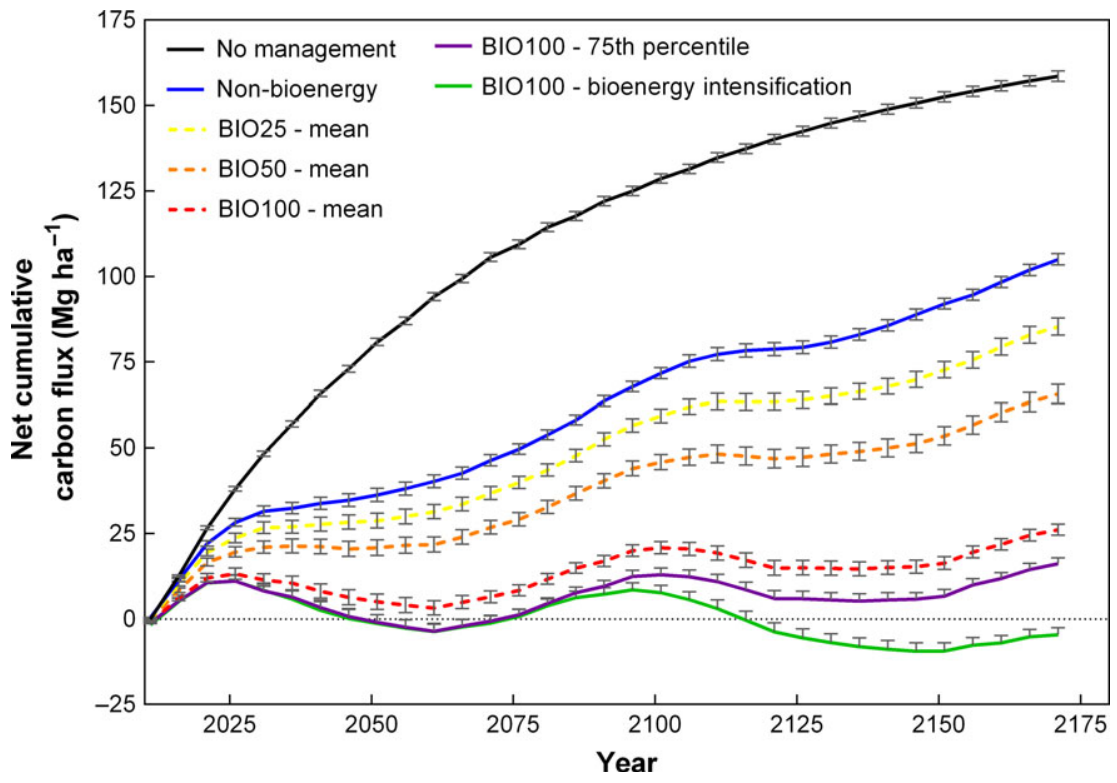

Fig. 2 Cumulative totals by scenario over the entire study period. The value at the end of the simulation (in 2171) is the 160-year net cumulative flux. The error bars are the standard error, calculated using the standard deviation of the cumulative totals of all 362 stands. 
Net cumulative $C$ fluxes from the landscape

Assessing the impact of bioenergy harvests in terms of net cumulative $C$ flux over the landscape after 160 years showed that using bioenergy for electricity generation resulted in positive net cumulative $C$ flux. On average, harvesting $25 \%, 50 \%$, or $100 \%$ of the stands for bioenergy resulted in net cumulative C flux of $85.33,65.70$, and $26.09 \mathrm{MgC} \mathrm{ha}{ }^{-1}$, respectively. However since the net cumulative C flux for bioenergy harvests $(85.33,65.70$, and $26.09 \mathrm{Mg} \mathrm{C} \mathrm{ha}^{-1}$ for BIO25, BIO50, and BIO100, respectively) was lower than that for non-bioenergy harvests (104.85 Mg C ha ${ }^{-1}$ ) across the landscape, bioenergy harvests resulted in net emissions to the atmosphere. Relative to non-bioenergy, BIO25, BIO50, and BIO100 scenarios resulted in additional absolute emissions of $-2.47,-5.02$, and $-9.83 \mathrm{MgC} \mathrm{ha}{ }^{-1} \mathrm{yr}^{-1}$, respectively (Fig. 3). A single-factor ANOVA and post hoc Tukey-Kramer HSD test showed that all scenarios differed from each other $(P<0.0001$ for all).

Repeating the analysis for BIO100 with the bioenergy going to heating instead of electricity generation affected the net cumulative $\mathrm{C}$ flux. A paired $t$-test showed that the net cumulative $C$ flux was higher when bioenergy was used for heating rather than electricity generation in the BIO100 scenario (landscape average of 39.40 and $26.09 \mathrm{Mg} \mathrm{C}^{-1}$, respectively; $P<0.0001$ ). Compared to non-bioenergy, using bioenergy for heating instead of electricity resulted in two additional stands having a positive net $C$ flux in any given year. Overall, there were an additional 39 stands, for a total of 337 that had a positive net cumulative $C$ flux when the bioenergy was used for heating instead of electricity. However, averaged across the landscape, the net cumulative C flux compared to non-bioenergy $(104.85 \mathrm{Mg}$ $\mathrm{C} \mathrm{ha}^{-1}$ ) was $65.44 \mathrm{Mg} \mathrm{C} \mathrm{ha}^{-1}$ lower.

The effects of harvesting on forest $C$ stocks varied by type of harvest. Averaged over the 160-year simulation period and among a collection of stands distributed over the landscape, all active management scenarios resulted in statistically significant reductions in the forest live tree and DCWD within the forest $C$ stocks $(P<0.0001$; Table 5; Fig. 4). The Tukey-Kramer HSD test revealed that the BIO100 scenario had lower live tree $\mathrm{C}$ (66.32 $\mathrm{Mg} \mathrm{C} \mathrm{ha}^{-1}$ ) than all other scenarios (67.54, 68.25, and $68.88 \mathrm{Mg} \mathrm{C} \mathrm{ha}^{-1}$ for BIO50, BIO25, and nonbioenergy, respectively; $P<0.05$ ). Compared to nonbioenergy, BIO100 had 2.56 fewer $\mathrm{Mg}$ of $\mathrm{C}$ per hectare in live trees (Fig. 4). The BIO50 scenario also had statistically lower live tree $\mathrm{C}$ than the BIO25 scenario $(P=0.0034$; Table 5; Fig. 4). However, there was no difference between the BIO25 and BIO50 $(P=0.31)$ or between the non-bioenergy and BIO25 scenarios $(P=0.46$; Table 5; Fig. 4). Furthermore, downed coarse woody debris differed between all active management scenarios $(P<0.0001$; Table 5; Fig. 4). This pool ranged from $15.04 \mathrm{Mg} \mathrm{C} \mathrm{ha}^{-1}$ for the non-bioenergy scenario to between 9.84 and $13.73 \mathrm{Mg} \mathrm{C}$ ha ${ }^{-1}$ for the bioenergy scenarios. The standing dead tree $\mathrm{C}$ was not statistically different between any active management scenarios $(P=0.35$; Table 3; Table 5; Fig. 4) and ranged 1.31$1.37 \mathrm{Mg} \mathrm{C} \mathrm{ha}{ }^{-1}$.

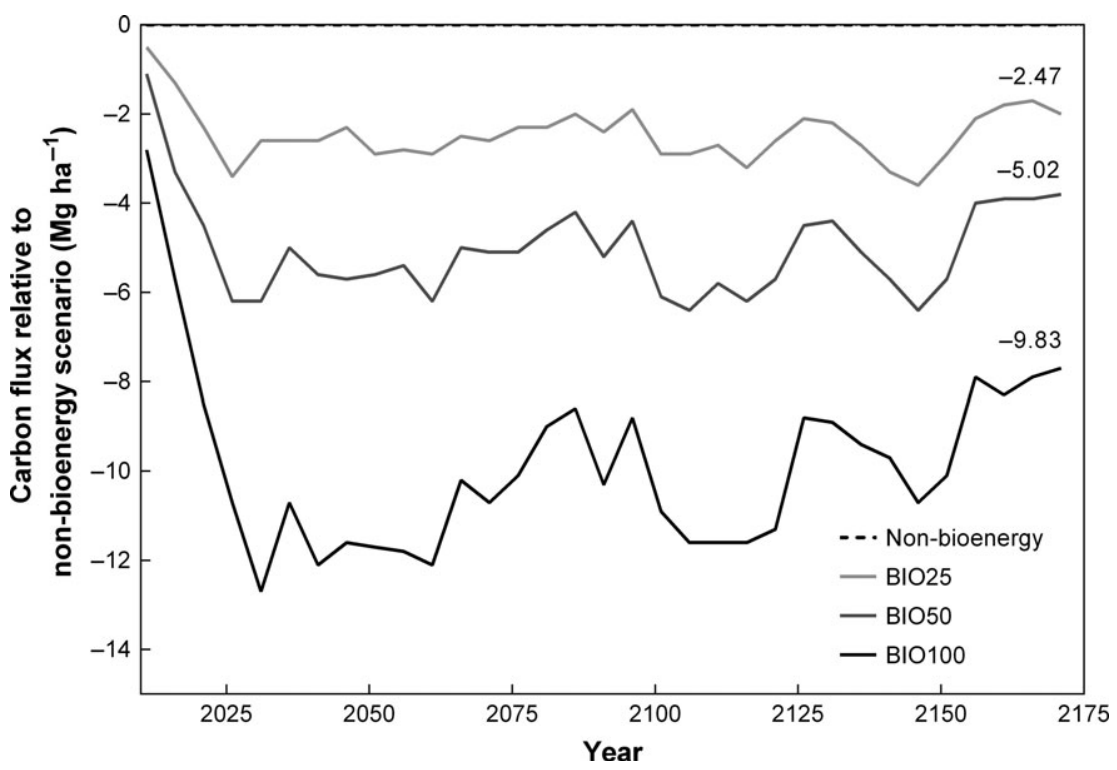

Fig. 3 Total carbon emitted relative to the non-bioenergy scenario (dashed line). The values above each line show the average of all 362 stands over the 160 years for each scenario. 
Table 5 Post hoc Tukey-Kramer HSD results comparing the average $\mathrm{C}$ in forest carbon pools and emissions between active management scenarios across 160 years when bioenergy is used for electricity generation. The active management scenarios included non-bioenergy and bioenergy scenarios. In the bioenergy scenarios either 25,50, or 100\% of the stands were harvested for bioenergy (named $\mathrm{BIO} 25, \mathrm{BIO50}$, and BIO100, respectively)

\begin{tabular}{|c|c|c|c|c|}
\hline Management scenario & C pool & $\mathrm{BIO} 25$ & BIO50 & BIO100 \\
\hline \multirow[t]{10}{*}{ Non-bioenergy } & Live tree & 0.4600 & 0.0034 & $<0.0001$ \\
\hline & Dead tree & 0.9905 & 0.7796 & 0.2779 \\
\hline & Down woody debris & $<0.0001$ & $<0.0001$ & $<0.0001$ \\
\hline & Wood products & 0.9839 & 0.8219 & 0.1607 \\
\hline & Emissions with energy capture & 0.9975 & 0.9625 & 0.5491 \\
\hline & Emissions without energy capture & 0.9978 & 0.9623 & 0.5569 \\
\hline & Wood product indirect emissions & 0.9995 & 0.9926 & 0.8885 \\
\hline & Bioenergy emissions & $<0.0001$ & $<0.0001$ & $<0.0001$ \\
\hline & Fossil fuel offsets & $<0.0001$ & $<0.0001$ & $<0.0001$ \\
\hline & Total C stored & $<0.0001$ & $<0.0001$ & $<0.0001$ \\
\hline \multirow[t]{10}{*}{$\mathrm{BIO} 25$} & Live tree & - & 0.3140 & $<0.0001$ \\
\hline & Dead tree & - & 0.9595 & 0.5549 \\
\hline & Down woody debris & - & $<0.0001$ & $<0.0001$ \\
\hline & Wood products & - & 0.9835 & 0.4222 \\
\hline & Emissions with energy capture & - & 0.9971 & 0.7568 \\
\hline & Emissions without energy capture & - & 0.9966 & 0.7559 \\
\hline & Wood product indirect emissions & - & 0.9995 & 0.9557 \\
\hline & Bioenergy emissions & - & $<0.0001$ & $<0.0001$ \\
\hline & Fossil fuel offsets & - & $<0.0001$ & $<0.0001$ \\
\hline & Total C stored & - & $<0.0001$ & $<0.0001$ \\
\hline \multirow[t]{10}{*}{ BIO50 } & Live tree & - & - & 0.0103 \\
\hline & Dead tree & - & - & 0.9228 \\
\hline & Down woody debris & - & - & $<0.0001$ \\
\hline & Wood products & - & - & 0.7618 \\
\hline & Emissions with energy capture & - & - & 0.9153 \\
\hline & Emissions without energy capture & - & - & 0.9195 \\
\hline & Wood product indirect emissions & - & - & 0.9886 \\
\hline & Bioenergy emissions & - & - & $<0.0001$ \\
\hline & Fossil fuel offsets & - & - & $<0.0001$ \\
\hline & Total C stored & - & - & $<0.0001$ \\
\hline
\end{tabular}

\section{Differences in carbon stores and emissions}

Comparing forest $\mathrm{C}$ pools between scenarios at the end of the 160-year simulation period revealed statistically significant differences in the DCWD pool. There was no statistically significant difference in aboveground live tree or snag $\mathrm{C}$ among active management scenarios $(P>0.05$ for both). There was a statistically significant difference in the downed DCWD pool between active management scenarios $(P<0.0001)$. A post hoc TukeyKramer HSD test showed that this difference can be attributed to the comparisons of BIO100 against all the other active scenarios $(P<0.001)$. The BIO50 scenario also differed from non-bioenergy scenario $(P=0.01)$.

There was no difference among active management scenarios in the net $C$ stored in wood products at the end of the simulation $(P>0.05)$. The resulting direct and indirect emissions (with and without energy capture) resulting from processing wood products (see Table 1 for definitions) also did not differ $(P>0.05)$. Emissions from bioenergy, and the avoided fossil fuel emissions, were higher for BIO100 (2.54 and $0.39 \mathrm{Mg}$ $\mathrm{C} \mathrm{ha}^{-1}$, respectively) and all active scenarios $(P<0.01)$ as well as between non-bioenergy and BIO50 $(P=0.02)$. Finally, the total net flux in any given year (total storage minus total emissions) was greater for non-bioenergy scenario than for the BIO100, BIO50, or BIO25 $(P<0.0001$ for all $)$ and for BIO25 compared to BIO100 $(P<0.05)$.

\section{Intensification of bioenergy harvests}

The post-harvest residual basal area modeled in bioenergy harvest scenarios strongly affected the net cumulative C flux. Using the 75th percentile (reduction of $12.5 \%$ in residual basal area for bioenergy scenario 


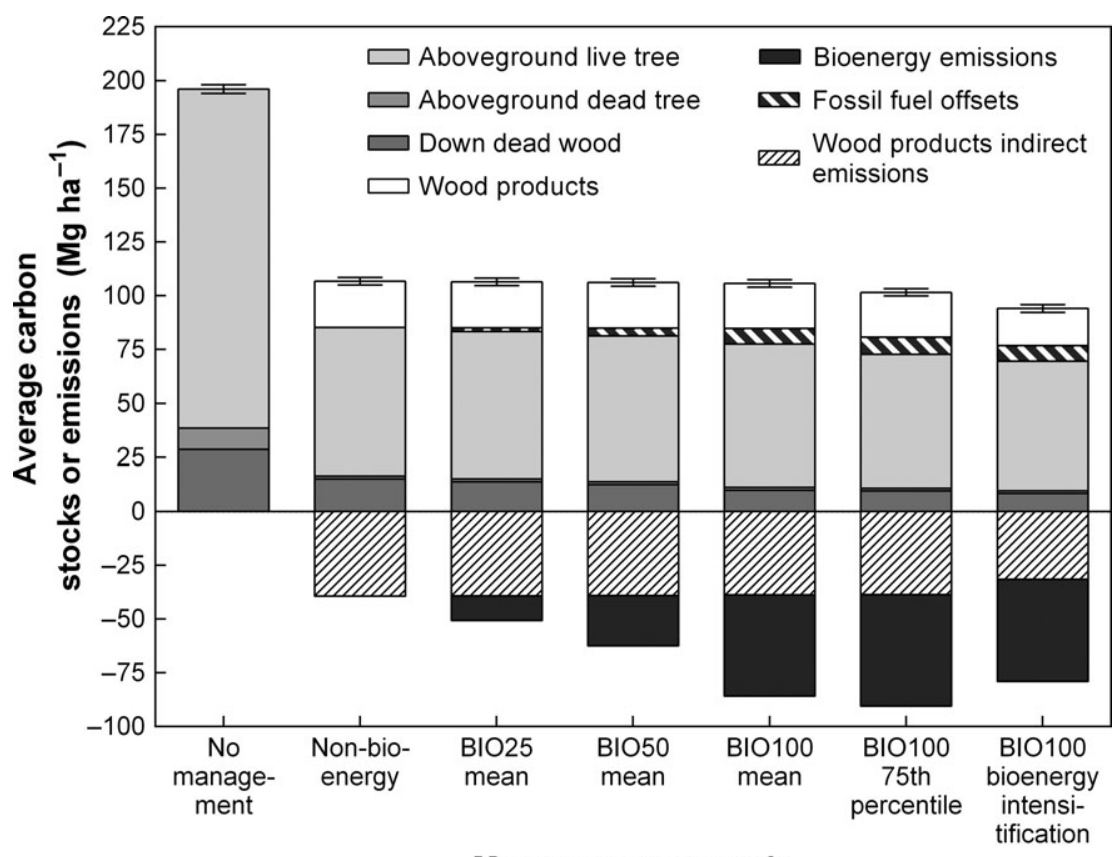

Management scenario

Fig. 4 Positive bars show aboveground forest C stocks, $\mathrm{C}$ in wood products, and displaced fossil fuel C emissions (offset). Negative bars show $\mathrm{C}$ emitted from the processing of wood products and burning of bioenergy for electricity generation. For each pool, the values are cumulative totals averaged across 362 stands and 160 years. The error bars show the pooled standard error for the total net $C$ flux. Subtracting the negative bars from the positive bars for each scenario gives average landscape net cumulative flux per year.

compared to non-bioenergy) from our field data rather than the mean (reduction of 3\%) significantly decreased the landscape net cumulative $C$ flux from 26.09 to 16.17 Mg C ha ${ }^{-1}$ (paired $t$-test; $P<0.0001$ ). Not setting a lower limit for basal area further significantly decreased the net cumulative $\mathrm{C}$ flux to $-4.62 \mathrm{Mg}$ $\mathrm{C}$ ha $^{-1}$ (paired $t$-test; $P<0.0001$ ). Both of these bioenergy scenarios with additional intensification were statistically different from all other scenarios (Tukey-Kramer HSD test; $P<0.0001$ for all except $P=0.22$ between BIO100 and 75th Percentile scenarios).

Including slash (unmerchantable tops) removed from intermediate thinnings scheduled between the shelterwood and clearcut regeneration harvests, allocated as volume for bioenergy, increased the net cumulative $C$ flux. This held for both electricity and heating BIO100 scenarios (paired $t$-test; $P<0.0001$ ). For electricity, removing slash from thinnings resulted in a net cumulative C flux of $30.25 \mathrm{Mg} \mathrm{C} \mathrm{ha}^{-1}$ (compared to $26.09 \mathrm{Mg}$ $\mathrm{C} \mathrm{ha}^{-1}$ when the thinnings were not removed). Including slash from thinnings and using it for heating increased the net cumulative $\mathrm{C}$ flux from 39.40 to 43.09 $\mathrm{Mg} \mathrm{C} \mathrm{ha}^{-1}$.

\section{Multivariate and sensitivity analysis}

The CART analysis showed that pre-harvest live biomass at the beginning of the simulation period (henceforth termed 'initial biomass') was the single strongest predictor of cumulative net $C$ fluxes (Fig. 5). Of the 12 independent variables assessed, only initial biomass was selected by the final CART model and assigned to multiple nodes in the tree. Stands with greater aboveground live tree biomass had a lower net cumulative $\mathrm{C}$ flux, including some with negative net cumulative $\mathrm{C}$ flux, than those with lower initial biomass (Fig. 5). Validating the CART results, a linear regression supported a negative correlation between 2011 aboveground live tree biomass and net cumulative $C$ flux (Fig. 6; $R^{2}=0.57 ; F=$ 485.6; $P<0.0001)$.

The sensitivity analysis showed that our decisions for specific details of the modeling scenarios, such as assigning bioenergy harvests to stands with the largest percentage of cull trees (relative to other stands in our sample), did not affect our results. Instead of assigning the bioenergy harvest to the stands with the largest percentage of cull trees for the BIO25 and BIO50 scenarios, we randomly assigned the harvests to $50 \%$ of the stands. A Tukey-Kramer HSD test showed that the net cumulative $\mathrm{C}$ flux in any given year from the BIO50 scenario was not statistically different from a BIO50 scenario where the bioenergy harvests were randomly assigned $(P=0.9992)$. The average net cumulative $\mathrm{C}$ flux across all years was also not different (paired $t$-test; $P=0.87)$. 


\section{Discussion}

Despite considerable debate in the literature (Schlamadinger et al., 1995; Johnson, 2009; Schulze et al., 2012; Zanchi et al., 2012), the results from this study strongly support the conclusion that wood bioenergy increases net emissions of $\mathrm{CO}_{2}$ to the atmosphere compared to timber management that does not allocate volume to bioenergy ('non-bioenergy'; Fig. 3). However, since all

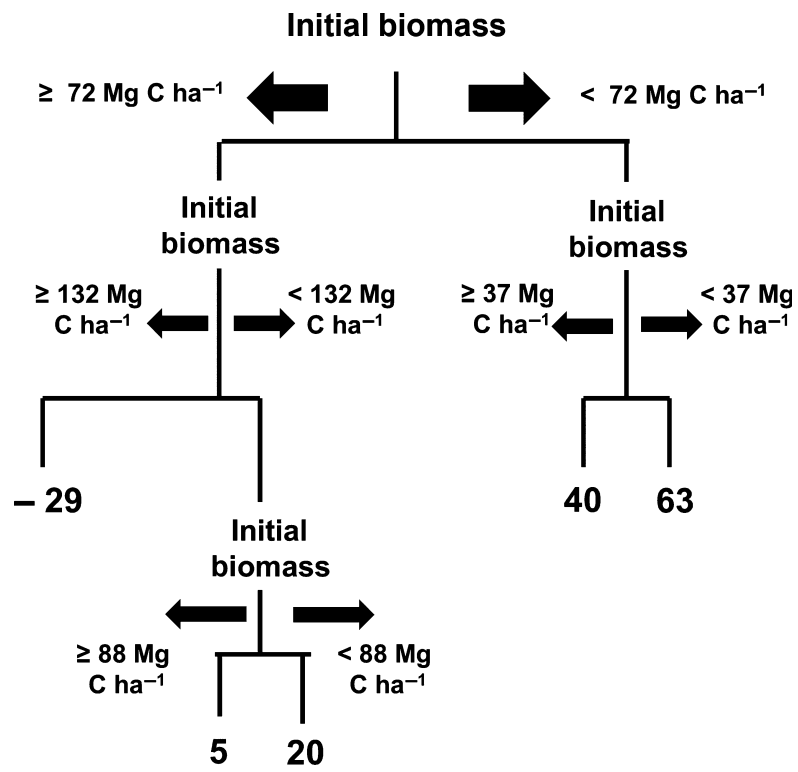

Fig. 5 Classification and Regression Tree analysis results. $R^{2}=0.587 ; \quad$ RMSE $=19.63 ; \quad N=362 ; \quad$ number of splits $=4$; AICc $=3194.87$. The values along the bottom are the mean net cumulative fluxes for that partition. Independent variables in analysis included those listed in Table 4 . bioenergy harvests resulted in positive net cumulative C flux, and thus did not increase $\mathrm{C}$ emissions over time (but rather both sequestered $\mathrm{C}$ and offset fossil fuel emissions), it is only in comparison to the emissions reductions that would have accrued from non-bioenergy harvesting (i.e., foregone net $\mathrm{C}$ flux potential) that this view emerges. Thus, choice of baseline yields profoundly contrasting conclusions about wood bioenergy emissions. Relative to starting landscape condition, all scenarios added carbon to terrestrial sinks and/or offset fossil fuel emissions, and could by this measure be considered carbon neutral. If foregone $\mathrm{C}$ sequestration potential (or 'opportunity cost') is the benchmark, and if harvest intensities increase, then our results show wood bioenergy to result in net increased emissions.

In previous studies of wood bioenergy, a primary focus has been on the length of the $\mathrm{C}$ debt and possible dividend through forest $C$ sequestration and fossil fuel offsets (McKechnie et al., 2011; Routa et al., 2011; Zanchi et al., 2012). In contrast, our study suggests that when bioenergy is part of a suite of forest products, although the net cumulative $C$ flux over the landscape is positive (i.e., a net sink of emissions), bioenergy harvests result in net emissions to the atmosphere compared to nonbioenergy harvests (Fig. 3). From this analytical perspective, we found no evidence of a long-term dividend. Our results are consistent with Peckham \& Gower (2013) who, using the Biome-BGC model, predict that under a scenario of expanded harvesting and replacement of traditional products with bioenergy production, the US Midwest is likely to shift from a carbon sink to a carbon source.

Many stands in our study were not able to recover from the more intense bioenergy harvests to their

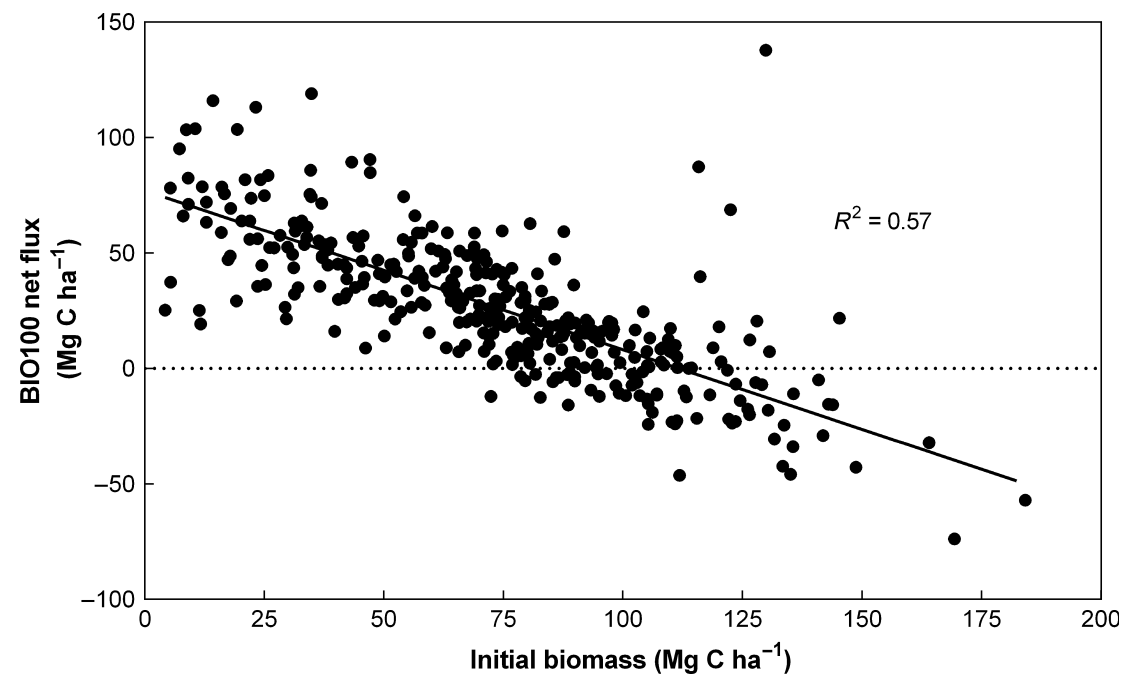

Fig. 6 Linear regression of net flux from BIO100 scenario and starting live biomass. $Y=-0.6891 * X+77.01$. 
starting aboveground live biomass stocks; therefore, the volume of wood products declined over time due to lack of harvestable material. Therefore, there was not only less $\mathrm{C}$ in the forest stand at the end of the simulation period but also less was harvested and transferred to wood products over time. Setting the residual basal area even lower, or removing the post-harvest minimal stocking requirement altogether, resulted in lower positive net cumulative $C$ fluxes, which were negative with no residual basal area limit. However since all our bioenergy harvest scenarios represented various degrees of intensification, the $\mathrm{C}$ dynamics may differ if bioenergy competes for wood products. Although this is currently not the case, future prices for woodchips, sawlogs, and pulp fiber will determine the allocation of harvested wood to these various uses (Eisenbies et al., 2009; Briedis et al., 2011a). Therefore, mitigation methods will need to focus on sustainable forest management and end-uses with the lowest net $C$ impacts.

\section{Variability between stands}

In our study, the majority of stands $(82 \%)$ that were harvested for bioenergy resulted in a net $\mathrm{C}$ benefit (storage plus avoided fossil fuel emission) at the end of the simulation period. However, all stands had a net emission in at least 1 year and 64 had a negative net cumulative $\mathrm{C}$ flux by the end of the simulation period. More importantly, the net cumulative $C$ flux over the landscape was lower for bioenergy harvests than non-bioenergy harvests, which results in net emissions to the atmosphere in any given year.

The multivariate CART analysis showed that of all the variables pertaining to stand characteristics and silvicultural prescription, the amount of live biomass at the start of the simulation had the largest impact on cumulative net $C$ flux. This was likely because stands with higher initial biomass were harvested earlier and, hence, had more rotations fit into the 160-year simulation, than those with lower initial biomass. Those with lower initial biomass grew until they reached the minimum stocking required for a harvest and were sequestering $\mathrm{C}$ during that time.

Although FVS is highly sensitive to site index, this independent variable did not surface as a top predictor of variability in cumulative net $C$ flux. We found that the initial amount of live biomass and end-use of bioenergy influences net $\mathrm{C}$ outcomes (Fig. 5). These results are consistent with Holtsmark (2013), who found bioenergy harvests are not C-neutral over the short- or longterm when harvest intensity is increased permanently. Our analysis suggest that fundamental conclusions about net $\mathrm{C}$ flux change when multiple harvests, staggered over time and space, are included in the analysis rather than just a single harvest with subsequent recovery (Holtsmark, 2013). Other researchers have also found that the starting landscape conditions as well as land-use history strongly influence the amount of time required to reach C-neutrality (Mitchell et al., 2012). However, in contrast to our study, the stands with greater biomass achieved a net $\mathrm{C}$ benefit relative to fossil fuels faster (Mitchell et al., 2012), while the stands in our study had the opposite relationship and never achieved a net $C$ benefit relative to non-bioenergy. Our results support the conclusion that if the stands with larger amount of biomass are harvested for bioenergy, the C debt, referred to as 'debit' by the authors, may be longer or never be achieved (Schlamadinger \& Marland, 1999).

\section{Differences in carbon neutrality accounting}

Researchers have found that choice of C-accounting method, such as whether only changes in forest $\mathrm{C}$ stocks are counted as opposed to total C sequestered and emitted (Johnson, 2009), strongly affect conclusions about the impacts of bioenergy harvesting on $\mathrm{C}$ fluxes. Other researchers have recommended including in the accounting full life-cycle analysis (Cherubini \& Strømman, 2011), wood product bioenergy substitutions (Eriksson et al., 2007), effects of multiple harvests (Holtsmark, 2013), and appropriate baselines (Johnson \& Tschudi, 2012), including a clear definition of the baseline (Helin et al., 2013).

The question of the baseline is particularly relevant because most previous bioenergy studies used a fossil fuel baseline (e.g., see Eriksson et al., 2007; Manomet Center for Conservation Sciences, 2010; McKechnie et al., 2011; Zanchi et al., 2012), while our study uses a non-bioenergy baseline. Johnson \& Tschudi (2012) identified four main baseline approaches in bioenergy studies: (i) no baseline; (ii) reference point; (iii) marginal fossil fuel; and (iv) biomass opportunity cost. In our study, we incorporated the latter three baselines, but also added a non-bioenergy baseline. The 'reference point' compares the $\mathrm{C}$ stocks at the beginning of the study to those at the end, the 'marginal fossil fuel' baseline illustrates the $\mathrm{C}$ emissions relative to those from the equivalent amount of energy generated from fossil fuels, and the 'biomass opportunity cost' shows the amount of biomass intentionally harvested for the purposes of energy generation (Johnson \& Tschudi, 2012). Comparing to a no management reference point as the baseline may be unrealistic. However, the drastic difference in net cumulative $\mathrm{C}$ flux from no management compared to all the active management scenarios makes a strong case for reserve-based management as one component on an integrated strategy designed to offset emissions from other sources (Nunery \& Keeton, 2010). 
Other researchers have found that choice of reference fossil fuel baseline strongly affects estimated net $\mathrm{C}$ fluxes (Eriksson et al., 2007; Manomet Center for Conservation Sciences, 2010; McKechnie et al., 2011). Since coal and oil emit more C per unit of energy produced than natural gas (Demirbas, 2001), replacing these with bioenergy may have greater net $\mathrm{C}$ benefits (Eriksson et al., 2007; Manomet Center for Conservation Sciences, 2010; Walker et al., 2012). Our study used natural gas as the reference fuel for heating and the Northeast regional grid fuel mix for electricity, which represents one of the cleanest fuel mixes in the United States. The NEWE grid has the sixth lowest emissions of any regional grid in the United States (Rothschild et al., 2009). The modeled emissions would likely have been higher (and net cumulative $\mathrm{C}$ fluxes lower) had we used a more carbonintensive electricity mix, such as those located in the Midwest. Similarly, the net cumulative C fluxes likely would have been higher if coal or oil was displaced for thermal instead of natural gas. However, despite using natural gas as the reference fossil fuel, the net cumulative $C$ fluxes from the bioenergy scenarios are likely to still be below the storage projected by either the no management or non-bioenergy scenarios.

\section{Reducing and mitigating emissions from bioenergy harvests}

Transitioning away from fossil fuels will require reductions in energy use, improved energy efficiency, and increased utilization of other renewable energy sources, such as wind and solar. However, there is also an important role for forests, and wood bioenergy may be part of the mix. Using bioenergy for heating instead of electricity, particularly in parts of the United States and other countries that rely on coal, may have greater benefit (Eriksson et al., 2007; Manomet Center for Conservation Sciences, 2010; McKechnie et al., 2011) than in the Northeast where bioenergy is displacing a less C-intensive fuel mix. Furthermore, careful selection of stands and treatment may decrease the net emissions from bioenergy harvests. Some poor quality stands with small stems and low stocking may benefit from rehabilitation treatments, such as a silvicultural clearcut or crop tree release (Russell-Roy et al., Inreview), where the harvested product is combusted for energy. However, we assigned silvicultural treatments and harvest schedules randomly rather than based on stocking, stand characteristics, or management objectives. Furthermore, aside from the thinnings between the shelterwood and clearcut harvests, the regeneration harvests themselves were scheduled by year, not based on site quality or volume of live biomass. Frequency and timing of harvests are important because there is an immediate post-harvest emission of C (Cherubini et al., 2011; Mika \& Keeton, 2013). Demand for bioenergy is likely to decrease harvest rotations (Schulze et al., 2012), which would result in more frequent post-harvest fluxes of $\mathrm{C}$. On the other hand, extending rotation periods, which is commonly accepted practice to increase forest C stocks (Liski et al., 2001; Peng et al., 2002; Ray et al., 2009b; Swanson, 2009; Keeton et al., 2011), may alleviate this additional initial $\mathrm{C}$ flux from bioenergy harvests.

Another way to reduce emissions from bioenergy harvest may be to increase the basal area threshold before a harvest occurs (i.e., waiting longer to harvest), which may also reduce indirect emissions from harvesting, based on our results and previous research (Liski et al., 2001; Alam et al., 2012). Although our study did not incorporate various levels of structural retention or rotation lengths for both non-bioenergy and bioenergy harvests, some stands were not harvested as heavily because they were limited by our minimum residual basal area specification. Removing this limit showed that although the emissions from bioenergy harvests did not increase, the $\mathrm{C}$ stocks in the forest and wood products decreased even further. This resulted in negative net cumulative $C$ flux over the landscape. In general, increasing in situ forest $\mathrm{C}$ by decreasing intensity and increasing structural retention results in greater forest C stocks (Harmon et al., 2009; Ray et al., 2009b; Nunery \& Keeton, 2010; Keeton et al., 2011), which decreases net $\mathrm{C}$ emissions. The Forest Guild (Forest Guild Biomass Working Group, 2010) and several US states have already proposed harvesting guidelines including retention standards, specific to bioenergy harvests. Retaining several large live and dead trees per hectare, as well as tree tops and slash, is beneficial because it aids in the recruitment of snags and DCWD and has additional biodiversity and habitat cobenefits (Littlefield \& Keeton, 2012).

Finally, some researchers have argued that the initial $\mathrm{C}$ emissions from bioenergy harvests from harvesting and combustion are offset by growing stands (Malmsheimer et al., 2011). In our study, all stands were harvested for either bioenergy or non-bioenergy and we did not include unmanaged reserves. However, integrated use of reserves, longer rotations, less intensive management, and staggered scheduling of bioenergy harvests, compensating for harvest emissions through regrowth in recovering stands, could further offset or minimize bioenergy harvests.

Ultimately, determining the optimal mix, type, and amount of wood bioenergy production within integrated regional energy portfolios will require deliberative public policy formulation and comprehensive C-accounting. Wood bioenergy is a renewable energy source that can provide local economic incentives for 
working forests as well as open space conservation. Hence, it has clear benefits that must be considered relative to emissions tradeoffs. Policy development will need to assess net emissions relative to different types of baselines, as in this study. From this standpoint, the missed opportunity to sequester carbon when assessed against a business as usual baseline will need to be evaluated against the favorable emissions profiles of bioenergy scenarios when assessed against a reference point baseline (e.g., starting $\mathrm{C}$ balance). However, both our study and previous research (Peckham \& Gower, 2013; Zanchi et al., 2012) clearly show that even the latter baseline is strongly affected by the degree to which future harvesting intensity increases, supporting a need for policies and guidelines aimed at minimizing this risk.

\section{Acknowledgements}

This study was supported by grants from the National Science Foundation (Award no. 0613884), the Northeastern States Research Cooperative, and the USDA McIntire-Stennis Forest Research Program. We thank the field crew, including Caitlin Littlefield, Isabel Beavers, and Emily Potter for helping us with field data collection. We also thank Donald Tobi, other foresters, and landowners for facilitating access to field sites. We thank Cecilia Danks, Don Ross, and Deane Wang for providing valuable constructive criticism on an earlier draft of this manuscript.

\section{References}

Alam A, Kilpeläinen A, Kellomäki S (2012) Impacts of initial stand density and thinning regimes on energy wood production and management-related $\mathrm{CO}_{2}$ emissions in boreal ecosystems. European Journal of Forest Research, 131, 655-667.

Bailey RG (2004) Identifying ecoregion boundaries. Environmental Management, 34, S14-S26.

Bankowski J, Dey D, Boysen E, Woods M, Rice J (1996) Validation of NE-TWIGS for Tolerant Hardwood Stands in Ontario. Ontario Ministry of Natural Resources, Ontario Forest Research Institute, Sault Ste. Marie, Ontario, Canada.

Birdsey RA (1992) Carbon Storage and Accumulation in United States Forest Ecosystems Gen. Tech. Rep. WO-59, Department of Agriculture, Forest Service, Washington, DC, USA.

Briedis JI, Wilson JS, Benjamin Jeffrey G, Wagner RG (2011a) Biomass retention following whole-tree, energy wood harvests in central Maine: adherence to five state guidelines. Biomass and Bioenergy, 35, 3552-3560.

Briedis JI, Wilson JS, Benjamin JG, Wagner RG (2011b) Logging residue volumes and characteristics following integrated roundwood and energy-wood whole-tree harvesting in central Maine. Northern Journal of Applied Forestry, 28, 66-71.

Buchholz T, Luzadis VA, Volk TA (2009) Sustainability criteria for bioenergy systems: results from an expert survey. Journal of Cleaner Production, 17 (Suppl. 1: S86-S98.

California Air Resources Board (2010) Local Government Operations Protocol for the Quantification and Reporting of Greenhouse Gas Emissions Inventories Version 1.1. California Air Resources Board, California Climate Action Registry, ICLEI - Local Governments for Sustainability, and The Climate Registry, Sacramento, CA, USA.

Cherubini F, Strømman AH (2011) Life cycle assessment of bioenergy systems: state of the art and future challenges. Bioresource Technology, 102, 437-451.

Cherubini F, Strømman AH, Hertwich E (2011) Effects of boreal forest management practices on the climate impact of $\mathrm{CO}_{2}$ emissions from bioenergy. Ecological Modelling, 223, 59-66.

Crookston NL, Dixon GE (2005) The forest vegetation simulator: a review of its structure, content, and applications. Computers and Electronics in Agriculture, 49 $60-80$
Davis SC, Hessl AE, Scott CJ, Adams MB, Thomas RB (2009) Forest carbon sequestration changes in response to timber harvest. Forest Ecology and Management, 258, 2101-2109.

De'ath G, Fabricius KE (2000) Classification and Regression Trees: a powerful yet simple technique for ecological data analysis. Ecology, 81, 3178-3192.

Demirbas A (2001) Biomass resource facilities and biomass conversion processing for fuels and chemicals. Energy Conversion and Management, 42, 1357-1378.

Domke GM, Becker DR, D'Amato AW, Ek AR, Woodall CW (2012) Carbon emissions associated with the procurement and utilization of forest harvest residues for energy, northern Minnesota, USA. Biomass and Bioenergy, 36, 141-150.

Eisenbies M, Vance E, Aust W, Seiler J (2009) Intensive utilization of harvest residues in southern pine plantations: quantities available and implications for nutrient budgets and sustainable site productivity. BioEnergy Research, 2, 90-98.

Eriksson E, Gillespie AR, Gustavsson L, Langvall O, Olsson M, Sathre R, Stendahl J (2007) Integrated carbon analysis of forest management practices and wood substitution. Canadian Journal of Forest Research, 37, 671-681.

Forest Guild Biomass Working Group (2010) Forest Biomass Retention and Harvesting Guidelines for the Northeast. Forest Guild, Santa Fe, New Mexico, USA.

Fredeen AL, Bois CH, Janzen DT, Sanborn PT (2005) Comparison of coniferous forest carbon stocks between old-growth and young second-growth forests on two soil types in central British Columbia, Canada. Canadian Journal of Forest Research, 35, 1411-1421.

Gunn JS, Ganz DJ, Keeton WS (2012) Biogenic vs. geologic carbon emissions and forest biomass energy production. GCB Bioenergy, 4, 239-242.

Harmon ME (2001) Carbon sequestration in forests: addressing the scale question. Journal of Forestry, 99, 24-29.

Harmon ME, Marks B (2002) Effects of silvicultural practices on carbon stores in Douglas-fir - western hemlock forests in the Pacific Northwest, U.S.A.: results from a simulation model. Canadian Journal of Forest Research, 32, 863-877.

Harmon ME, Moreno A, Domingo JB (2009) Effects of partial harvest on the carbon stores in Douglas-fir/western hemlock forests: a simulation study. Ecosystems, 12, 777-791.

Helin T, Sokka L, Soimakallio S, Pingoud K, Pajula T (2013) Approaches for inclusion of forest carbon cycle in life cycle assessment - a review. GCB Bioenergy, 5 , 475-486.

Holtsmark B (2013) The outcome is in the assumptions: analyzing the effects on atmospheric $\mathrm{CO}_{2}$ levels of increased use of bioenergy from forest biomass. GCB Bioenergy, 5, 467-473.

Hoover C, Stout S (2007) The carbon consequences of thinning techniques: stand structure makes a difference. Journal of Forestry, 105, 266-270.

Hudiburg TW, Law BE, Wirth C, Luyssaert S (2011) Regional carbon dioxide implications of forest bioenergy production. Nature Climate Change, 1, 419-423.

Jenkins JC, Chojnacky DC, Heath LS, Birdsey RA (2003) National-scale biomass estimators for United States tree species. Forest Science, 49, 12-35.

Johnson E (2009) Goodbye to carbon neutral: getting biomass footprints right. Environmental Impact Assessment Review, 29, 165-168.

Johnson DW, Curtis PS (2001) Effects of forest management on soil C and N storage: meta analysis. Forest Ecology and Management, 140, 227-238.

Johnson E, Tschudi D (2012) Baseline effects on carbon footprints of biofuels: the case of wood. Environmental Impact Assessment Review, 37, 12-17.

Keeton WS (2006) Managing for late-successional/old-growth characteristics in northern hardwood-conifer forests. Forest Ecology and Management, 235, 129-142.

Keeton WS, Franklin JF (2005) Do remnant old-growth trees accelerate rates of succession in mature Douglas-fir forests? Ecological Monographs, 75, 103-118.

Keeton WS, Kraft CE, Warren DR (2007) Mature and old-growth riparian forests: structure, dynamics, and effects on Adirondack stream habitats. Ecological Applications, 17, 852-868.

Keeton WS, Whitman AA, McGee GC, Goodale CL (2011) Late-successional biomass development in northern hardwood-conifer forests of the northeastern United States. Forest Science, 57, 489-505.

Lamsal S, Cobb RC, Hall Cushman J, Meng Q, Rizzo DM, Meentemeyer RK (2011) Spatial estimation of the density and carbon content of host populations for Phytophthora ramorum in California and Oregon. Forest Ecology and Management, 262, 989-998.

Lattimore B, Smith CT, Titus BD, Stupak I, Egnell G (2009) Environmental factors in woodfuel production: opportunities, risks, and criteria and indicators for sustainable practices. Biomass and Bioenergy, 33, 1321-1342.

Leak WB (2005) Field Note - Effects of small patch cutting on sugar maple regeneration in New Hampshire northern hardwoods. Northern Journal of Applied Forestry, 22, 68-70. 
Leak WB, Solomon DS, DeBald PS (1987) Silvicultural Guide for Northern Hardwood Types in the Northeast (revised). Res. Pap. NE-603, Department of Agriculture, Forest Service, Northeastern Forest Experiment Station, Broomall, Pennsylvania, USA.

Lippke B, Gustafson R, Venditti R et al. (2011) Sustainable biofuel contributions to carbon mitigation and energy independence. Forests, 2, 861-874.

Liski J, Pussinen A, Pingoud K, M. R., and T. Karjalainen. (2001) Which rotation length is favourable to carbon sequestration? Canadian Journal of Forest Research, 31, 2004-2013.

Littlefield CE, Keeton WS (2012) Effects of wood bioenergy harvesting on ecologically important stand structure characteristics in northern hardwood forests. Ecological Applications, 22, 1892-1909.

Malmsheimer RW, Heffernan P, Brink S et al. (2008) Forest management solutions for mitigating climate change in the United States. Journal of Forestry, 106, 115-118.

Malmsheimer RW, Bowyer JL, Fried JS et al. (2011) Managing forests because carbon matters: integrating energy, products, and land management policy. Journal of Forestry, 109, S7-S51(45).

Manomet Center for Conservation Sciences (2010) Massachusetts Biomass Sustainability and Carbon Policy Study: Report to the Commonwealth of Massachusetts. Department of Energy Resources. Natural Capital Initiative Report NCI-2010-03, Brunswick, Maine, USA.

McKechnie J, Colombo S, Chen J, Mabee W, MacLean HL (2011) Forest bioenergy or forest carbon? Assessing trade-offs in greenhouse gas mitigation with woodbased fuels. Environmental Science \& Technology, 45, 789-795.

Mika AM, Keeton WS (2013) Factors contributing to carbon fluxes from bioenergy harvests in the U.S. Northeast: an analysis using field data. GCB Bioenergy, 5, 290-305.

Mitchell SR, Harmon ME, O'Connell KEB (2012) Carbon debt and carbon sequestration parity in forest bioenergy production. GCB Bioenergy, 4, 818-827.

Nave LE, Vance ED, Swanston CW, Curtis PS (2010) Harvest impacts on soil carbon storage in temperate forests. Forest Ecology and Management, 259, 857-866.

Nunery JS, Keeton WS (2010) Forest carbon storage in the northeastern United States: net effects of harvesting frequency, post-harvest retention, and wood products. Forest Ecology and Management, 259, 1363-1375.

Ollinger SV, Aber JD, Reich PB, Freuder RJ (2002) Interactive effects of nitrogen deposition, tropospheric ozone, elevated $\mathrm{CO}_{2}$ and land use history on the carbon dynamics of northern hardwood forests. Global Change Biology, 8, 545-562.

Ollinger SV, Goodale CL, Hayhoe K, Jenkins JP (2008) Potential effects of climate change and rising $\mathrm{CO}_{2}$ on ecosystem processes in northeastern U.S. forests. Mitigation and Adaptation Strategies for Global Change, 13, 467-485.

Pastor J, Post W (1986) Influence of climate, soil moisture, and succession on forest carbon and nitrogen cycles. Biogeochemistry, 2, 3-27.

Peckham SD, Gower ST (2013) Simulating the effects of harvest and biofuel production on the forest system carbon balance of the Midwest, USA. GCB Bioenergy, 5 , 431-444.

Peng C, Jiang H, Apps MJ, Zhang Y (2002) Effects of harvesting regimes on carbon and nitrogen dynamics of boreal forests in central Canada: a process model simulation. Ecological Modelling, 155, 177-189.

Ray DG, Saunders MR, Seymour RS (2009a) Recent changes to the Northeast variant of the Forest Vegetation Simulator and some basic strategies for improving model outputs. Northern Journal of Applied Forestry, 26, 31-34.

Ray DG, Seymour RS, Scott NA, Keeton WS (2009b) Mitigating climate change with managed forests: balancing expectations, opportunity, and risk. Journal of Forestry, $107,50-51$.

Rothschild SS, Quiroz C, Salhotra M, Diem A (2009) The Value of eGRID and eGRIDweb to GHG Inventories. U.S. Environmental Protection Agency, Washington, Columbia, USA.
Routa J, Kellomäki S, Kilpeläinen A, Peltola H, Strandman H (2011) Effects of forest management on the carbon dioxide emissions of wood energy in integrated production of timber and energy biomass. GCB Bioenergy, 3, 483-497.

Russell-Roy E, Keeton WS, Pontius JA, Kerchner CD (Inreview) Rehabilitation Forestry and Carbon Market Access on High-graded Northern Hardwood Forests. Canadian Journal of Forest Resources, Cary, NC.

SAS Institute Inc. 2010. JMP software version number, 9.0.0

Sathre R, Gustavsson L (2011) Time-dependent climate benefits of using forest residues to substitute fossil fuels. Biomass and Bioenergy, 35, 2506-2516.

Schlamadinger B, Marland G (1999) Net effect of forest harvest on $\mathrm{CO}_{2}$ emissions to the atmosphere: a sensitivity analysis on the influence of time. Tellus B, 51, 314 325

Schlamadinger B, Spitzer J, Kohlmaier GH, Lüdeke M (1995) Carbon balance of bioenergy from logging residues. Biomass and Bioenergy, 8, 221-234.

Schulze E-D, Körner C, Law BE, Haberl H, Luyssaert S (2012) Large-scale bioenergy from additional harvest of forest biomass is neither sustainable nor greenhouse gas neutral. GCB Bioenergy, 4, 611-616.

Schwenk WS, Donovan TM, Keeton WS, Nunery JS (2012) Carbon storage, timber production, and biodiversity: comparing ecosystem services with multi-criteria decision analysis. Ecological Applications, 22, 1612-1627.

Seymour RS, White AS, deMaynadier PG (2002) Natural disturbance regimes in northeastern North America - evaluating silvicultural systems using natural scales and frequencies. Forest Ecology and Management, 155, 357-367.

Smith JE, Heath LS, Skog KE, Birdsey RA (2006) Methods for Calculating Forest Ecosystem and Harvested Carbon with Standard Estimates for Forest Types of the United States. Gen. Tech. Rep. NE-343, Department of Agriculture, Forest Service, Northeastern Research Station, Newtown Square, Pennsylvania, USA

Smith WB, Miles PD, Perry CH, Pugh SA (2009) Forest Resources of the United States, 2007. Gen. Tech. Rep. WO-78, Department of Agriculture, Forest Service, Washington Office, Washington, DC, U.S.A

Solomon S, Plattner GK, Knutti R, Friedlingstein P (2009) Irreversible climate change due to carbon dioxide emissions. Proceedings of the National Academy of Sciences, 106, 1704-1709.

Swanson ME (2009) Modeling the effects of alternative management strategies on forest carbon in the Nothofagus forests of Tierra del Fuego, Chile. Forest Ecology and Management, 257, 1740-1750.

Walker T, Cardellichio P, Gunn JS, Saah DS, Hagan JM (2012) Carbon accounting for woody biomass from Massachusetts (USA) managed forests: a framework for determining the temporal impacts of wood biomass energy on atmospheric greenhouse gas levels. Journal of Sustainable Forestry, 32, 130-158

Wamelink GWW, Wieggers HJJ, Reinds GJ, Kros J, Mol-Dijkstra JP, van Oijen M, de Vries W (2009) Modelling impacts of changes in carbon dioxide concentration, climate and nitrogen deposition on carbon sequestration by European forests and forest soils. Forest Ecology and Management, 258, 1794-1805.

Westerling AL, Hidalgo HG, Cayan DR, Swetnam TW (2006) Warming and earlier spring increase western U.S. forest wildfire activity. Science, 313, 940-943.

Xu C, Gertner GZ, Scheller RM (2009) Uncertainties in the response of a forest landscape to global climatic change. Global Change Biology, 15, 116-131.

Zanchi G, Pena N, Bird N (2012) Is woody bioenergy carbon neutral? A comparative assessment of emissions from consumption of woody bioenergy and fossil fuel GCB Bioenergy, 4, 761-772.

Zummo LM, Friedland AJ (2011) Soil carbon release along a gradient of physical disturbance in a harvested northern hardwood forest. Forest Ecology and Management, 261, 1016-1026. 